\title{
CDKN1A is a target for phagocytosis-mediated cellular immunotherapy in acute leukemia
}

Awatef Allouch ${ }^{1-3 *}$, Laurent Voisin 1,2, Yanyan Zhang 2,4, Raza Syed 1,2,5, Yann Lecluse ${ }^{2,6}$, Julien Calvo ${ }^{7-9}$, Dorothée Sélimoglu-Buet ${ }^{2,10}$, Stéphane De Botton ${ }^{2}$, Fawzia Louache ${ }^{2,11}$, Françoise Pflumio $^{7-9}$, Eric Solary 2,10 and Jean-Luc Perfettini $1,2,12 *$

Université Paris-Saclay, Inserm UMR1030, Laboratory of Molecular Radiotherapy and Therapeutic Innovation, Villejuif, F-94805, France; Gustave Roussy Cancer Center, F-94805 Villejuif, France;

NH TherAguix, Meylan, F-38240, France;

4 Inserm U955, Université Paris-Est Créteil (UPEC), Créteil, F-94100, France;

5 Institute of Biochemistry and Biotechnology, University of Veterinary and Animal Sciences-UVAS, Lahore, Pakistan;

${ }^{6}$ Université Paris-Saclay, UMS 3655 CNRS / US 23 INSERM, Imaging and Cytometry Platform, Villejuif, F-94805, France; Inserm U1274, Team Niche and Cancer in Hematopoiesis, Fontenay-aux-Roses, F-92260, France;

${ }^{8}$ Commissariat à l'Energie Atomique et aux Energies Alternatives (CEA), Fontenay-aux-Roses, F-92260, France;

${ }^{9}$ Unité de Recherche (UMR)-E008 Stabilité Génétique, Cellules Souches et Radiations, Université de Paris-Université Paris-Saclay, Fontenay-aux-Roses, F-92260, France;

${ }^{10}$ Université Paris-Saclay, Inserm UMR1287, Hematopoietic stem cells and the development of myeloid malignancies, Villejuif, F-94805, France;

${ }^{11}$ Université Paris-Saclay, Inserm UMR-S-MD1197, Hôpital Paul Brousse, Villejuif, F-94800, France;

${ }^{12}$ Department of Biomedical Sciences, University of the Pacific, Arthur A. Dugoni School of Dentistry, 155 Fifth Street, CA-94103, San Francisco USA.

"Corresponding author.

${ }^{*}$ Correspondence to:
Dr. Jean-Luc PERFETTINI

Laboratory of Molecular Radiotherapy and Therapeutic Innovation, INSERM UMR1030 Université Paris-Saclay, Institut Gustave Roussy, Pavillon de Recherche 1

114 rue Edouard Vaillant

F-94805 Villejuif, France

Tel. 33-1-42 115424

Fax 33-1-42 115236

e-mail : jean-luc.perfettini@gustaveroussy.fr

\section{Dr. Awatef ALLOUCH}

Laboratory of Molecular Radiotherapy and Therapeutic Innovation, INSERM UMR1030 Université Paris-Saclay, Institut Gustave Roussy, Pavillon de Recherche 1

114 rue Edouard Vaillant

F-94805 Villejuif, France

Tel. $\quad 33-1-42115296$

Fax 33-1-42 115236

e-mail : awatef.allouch@gustaveroussy.fr 


\section{Summary}

Most tumor-associated macrophages (TAMs), which are abundant in the tumor microenvironment, demonstrate an immunosuppressive phenotype and contribute to tumor progression, treatment resistance and poor clinical outcomes ${ }^{1,2}$. Due to their functional plasticity, these cells could be reprogrammed to acquire a pro-inflammatory phenotype and promote tumor clearance ${ }^{1}$. Several therapeutic approaches targeting TAMs to alleviate their immunosuppressive properties or to harness their tumoricidal capacities have been developed $^{3,4}$. Inhibition of interactions between phagocytic inhibitor receptors on macrophages and "don't eat me signals" on cancer cells, which promotes cancer cell engulfment, showed therapeutic benefits for several tumor types ${ }^{4-6}$. Investigating mechanisms involved in macrophage-mediated phagocytosis of tumor cells, we demonstrate here a key role for the cyclin-dependent kinase inhibitor CDKN1A (p21). Through transcriptional repression of $\operatorname{SIRP} \alpha$ (Signal-Regularity Protein $\alpha)$, which encodes a phagocytic inhibitor, CDKN1A promotes the ability of monocyte-derived macrophages (MDMs) to engulf leukemic cells. In turn, these MDMs acquire a pro-inflammatory phenotype that extends to surrounding MDMs in an Interferon $\gamma($ IFN $\gamma)$-dependent manner. Human monocytes genetically engineered to overexpress p21 (p21TD-Mo) differentiate into anti-inflammatory MDMs that are primed for leukemic cell phagocytosis when transferred into mice xenografted with patient-derived T-cell acute lymphoblastic leukemia (T-ALL) cells. After leukemic cell engulfment, engineered macrophages undergo a pro-inflammatory activation, reducing leukemic burden and substantially prolonging survival of mice. These results reveal p21 as a trigger of phagocytosis-guided pro-inflammatory reprogramming of TAMs and demonstrate the potential for $\mathrm{p} 21 \mathrm{TD}-\mathrm{Mo}$-based cell therapy in cancer immunotherapy. 


\section{Main text}

Phagocytosis of cancer cells by macrophages plays a critical role in cancer immunosurveillance ${ }^{7,8}$. Cancer cells can evade macrophage-mediated phagocytosis by upregulating "don't eat me signals" on their surfaces such as CD47, PDL-1, $\beta 2 \mathrm{M}$ and CD24, which bind to the phagocytic inhibitor receptors SIRP $\alpha$, PD-1, LILRB1 and Siglec-10, respectively $^{7,9-12}$. These interactions trigger intracellular cascades of inhibitory signals in macrophages to block cytoskeletal rearrangements, the formation of phagocytic synapses and the engulfment of cancer cells ${ }^{7,9-13}$. Several immunotherapies aim to disrupt these interactions, through the use of macrophage immune checkpoint blockers (MICB) (such as blocking antibodies or antagonist engineered SIRP $\alpha$ variants), to circumvent negative signaling of phagocytosis, enabling macrophages to engulf and clear cancer cells ${ }^{7,9-12,14,15}$. However, the resistance of various cancer cells to the MICB reveals the existence of yet unknown regulatory mechanisms of tumor phagocytosis.

Human blood MDMs, which possess an anti-inflammatory phenotype ${ }^{16}$, were co-cultured with several leukemic cell lines (Fig. 1a). MDMs rapidly engulfed Jurkat T cells (Fig. 1b) and delivered them to lysosomal compartments for degradation, as visualized by confocal microscopy (Extended Data Fig. 1a). MDMs demonstrated phagocytic activity toward two other T-ALL cell lines (MOLT4 or CEM) without engulfment of primary peripheral blood lymphocytes (PBLs) (Fig. 1c). In these co-culture conditions, MDMs also engulfed acute myeloid leukemia (AML) cells such as the THP1 cell line (Fig. 1c) and primary AML blast cells (Fig. 1d) (Extended Data Table1), but failed to engulf erythroleukemic HEL cells and chronic myelogenous leukemic K562 cells (Fig. 1c), indicating that MDMs engulfed preferentially acute leukemia cells. In accordance with the previously demonstrated role of ROCK-dependent signaling pathways in phagocytosis ${ }^{17}$, MDM engulfment of leukemic cells and cell lines may depend on ROCK activity, as the pharmacological inhibition of ROCK 
kinase activity with Y27632 (as revealed by the inhibition of myosin light chain 2 phosphorylation on serine 19 (MLC2S19*) (Extended Data Fig. 1b)) abolished Jurkat cell phagocytosis (Extended Data Fig. 1c). In contrast, neither the broad spectrum-caspase inhibitor (ZVAD) (Fig. 1c,d) nor recombinant human annexin V (Extended Data Fig. 1d,e), which respectively impair apoptosis and the uptake of dying cells by macrophages, reduced the engulfment of Jurkat cells and primary AML blast cells, thus excluding efferocytosis ${ }^{18}$. We also excluded a role for target cell geometry since no correlation was identified between the phagocytosis of leukemic cells and the target cell's volume and surface area as determined by confocal microscopy (Extended Data Fig. 1f,g).

In order to explore the functional impact of leukemic cell phagocytosis on MDM phenotype, we cultured MDMs with MOLT4 cells for 2 hours before sorting phagocytic ( $\mathrm{Phago}^{+} \mathrm{MDMs}$ ) and non-phagocytic (Phago-MDMs) cells. Phago ${ }^{+}$MDMs (Fig. 1e-g) showed a complete degradation of engulfed cells 96 hours after cell sorting (Fig. 1h,i). Gene expression analysis indicated that, after degradation of target cells, Phago ${ }^{+} \mathrm{MDMs}$ underwent pro-inflammatory activation (Fig. 1j and Extended Data Table 2), as indicated by the up-regulation of 40 proinflammatory genes and down-regulation of 19 anti-inflammatory genes, compared with Phago`MDMs (Fig. 1j, Extended Data Table 2). Consistently, Phago ${ }^{+}$MDMs demonstrated decreased expression of the cell surface scavenger receptor CD163 (Fig. 1k), increased expression of the transcription factor IRF5 (Interferon regulatory factor 5, Fig. 11), and enhanced release of pro-inflammatory cytokines including IL1 $\beta$, IL6, IL8, SERPIN E1, GMCSF, IFN $\gamma$, IL23, Gro- $\alpha$, IL1-ra, MIF and IL27 (Fig. 11,m and Extended Data Fig. 2a), compared with Phago`MDMs. Similarly, $\mathrm{Phago}^{+} \mathrm{MDMs}$ that have engulfed primary AML blast cells demonstrated increased secretion of IL8, compared with Phago`MDMs (Extended Data Fig. 2b). 
Considering that Interferon $\gamma$ (IFN $\gamma$ ), which was secreted by Phago ${ }^{+}$MDMs (Fig. 1m), can potentially modulate the expression of 53 target genes in Phago ${ }^{+}$MDMs (Extended Data Table 2) and convert immunosuppressive TAMs into immunostimulatory macrophages ${ }^{19,20}$, we next explored the ability of secreted IFN $\gamma$ to promote the proinflammatory reprogramming of surrounding Phago ${ }^{-M D M s . ~ P h a g o ~}{ }^{+} \mathrm{MDMs}$ in the upper chamber of trans-well devices were co-cultured with Phago-MDMs in the bottom chamber, in the absence or presence of control IgG or anti-IFN $\gamma$ blocking antibodies for 15 days (Fig. 1n). While increased expression of the pro-inflammatory inducible oxide synthase (iNOS) was detected in Phago MDMs in the presence of control IgG, this effect was lost in the presence of anti-INF $\gamma$-blocking antibodies (Fig. 1o), demonstrating that Phago ${ }^{+} \mathrm{MDMs}$ could subsequently convert bystander antiinflammatory MDMs to a pro-inflammatory phenotype.

In order to identify molecular mechanisms regulating the macrophage-mediated phagocytosis of leukemic cells, we assessed the role of p21, which has been involved in differentiation and survival of macrophages ${ }^{21-24}$. Using specific small interfering RNA, MDMs were depleted for p21 (Fig. 2a) and assessed for phagocytosis. Interestingly, p21 depletion strongly reduced phagocytosis of Jurkat cells (Fig. 2b,c), MOLT4 cells (Fig. 2d) and primary human AML blast cells (Fig. 2e), without affecting the phagocytosis of pHrodo green bacterial E. coli bioparticles (Fig. 2f). These results suggested that p21 is a key regulator of the MDMmediated phagocytosis of leukemic cells. Inversely, increased p21 expression (Extended Data Fig. 3a,b,f) by treatment of MDMs with phorbol myristate acetate (PMA) ${ }^{25}$, histone deacetylase (HDAC) inhibitor MS275 ${ }^{26}$ or intravenous immunoglobulins (IVIg) ${ }^{16}$, significantly enhanced the phagocytosis of Jurkat cells and MOLT4 cells (Extended Data Fig. $3 \mathrm{c}-\mathrm{e}, \mathrm{g})$, confirming that $\mathrm{p} 21$ is a master regulator of MDM-mediated phagocytosis of leukemic cells. 
To elucidate the molecular mechanisms promoting p21-dependent phagocytosis of leukemic cells, we evaluated simultaneously the expression of p21 and SIRP $\alpha$, which is the main negative regulator of macrophage-mediated tumor cell phagocytosis ${ }^{27}$. Depletion of p21 in macrophages increased protein expression (Fig. 2g) and mRNAs of SIRP $\alpha$ (Fig. 2h,i), indicating that $\mathrm{p} 21$ down-regulates SIRP $\alpha$ protein through inhibition of its transcription. Reciprocally, up-regulation of p21 through transduction of MDMs with p21-expressing lentiviral vector (p21TD) (Fig. 2j) or with PMA treatment (Extended Data Fig. 3j) decreased the expression of SIRP $\alpha$ protein. Consistently, SIRP $\alpha$ mRNA was decreased in p21transduced (p21TD) macrophages, compared with control-transduced (Co.TD) macrophages (Fig. 2k,1), further indicating that p21 represses the transcription of SIRP $\alpha$.

Various mechanisms were shown to account for the ability of p21 to negatively regulate gene transcription $^{16,28,29}$. Using chromatin immunoprecipitation (ChIP)-qPCR assays, p21 was detected at the level of SIRP $\alpha$ promoter in MDMs, and p21 overexpression was observed to significantly increase its binding to SIRP $\alpha$ promoter (Fig. $2 \mathrm{~m}$ ). When MDMs in which p21 expression had been decreased (Fig. 2n) or enforced (Fig. 2o) were transduced with a lentiviral vector expressing luciferase reporter gene under control of the endogenous macrophage SIRP $\alpha$ promoter, we observed, respectively, an increase or a decrease in SIRP $\alpha$ promoter-dependent luciferase activity, further demonstrating that $\mathrm{p} 21$ could repress SIRP $\alpha$ gene transcription. To evaluate the impact of the CDKN1A-SIRP $\alpha$ axis on leukemic cell phagocytosis, MOLT4 cells stably expressing fluorescent mCherry reporter gene (mCherry ${ }^{+}$MOLT4) were co-cultured with MDMs generated from genetically engineered human monocytes (Mo) transduced with an empty (Co.TD-Mo), a CDKN1A-expressing (p21TD-Mo), a SIRP $\alpha$-expressing (SIRP $\alpha$ TD-Mo) lentiviral vector or combination of lentiviral vectors ( $\mathrm{p} 21+\mathrm{SIRP} \alpha \mathrm{TD}-\mathrm{Mo})$. To overcome $\mathrm{p} 21$-mediated repression of $S I R P \alpha$, we used a promoter, which was distinct from endogenous macrophage SIRP $\alpha$ 
promoter and did not respond to p21. As expected, enforced p21 expression decreased endogenous expression of SIRP $\alpha$ protein (Fig. 2p) and enhanced phagocytosis of mCherry ${ }^{+}$MOLT4 cells (Fig. 2q,r), while enforced expression of SIRP $\alpha$ (Fig. 2p) inhibited phagocytosis (Fig. 2q,r). Most importantly, transduction of a SIRP $\alpha$ cDNA that was insensitive to $\mathrm{p} 21$ repression abrogated phagocytosis of $\mathrm{mCherry}^{+} \mathrm{MOLT} 4$ cells by $\mathrm{p} 21$ overexpressing macrophages (Fig. 2p,q,r), demonstrating that p21-induced phagocytosis depends on SIRP $\alpha$ biological activity. p21 is unlikely to be involved in pro-inflammatory reprogramming of MDMs following leukemic cell engulfment, since p21 overexpression did not decrease cell surface expression of CD163 (Extended Data Fig. 3i), nor did it affect IRF5 expression (Extended Data Fig. 3j).

To explore how p21-mediated modulation of MDM phagocytic activity toward leukemic cells could be used therapeutically, we first showed that adoptive transfer of CFSE-labeled human monocytes in total body irradiated NOD.Cg-Prkdc $c^{\text {scid }} I l 2 r g^{\text {tml }}{ }^{W j l} / \mathrm{SzJ}$ (NSG) mice could generate $\mathrm{CFSE}^{+}$anti-inflammatory macrophages, detected in the bone marrow and the spleen within 7 days after monocyte adoptive transfer (Extended Data Fig. 4a-c,f). mCherry ${ }^{+}$MOLT4 cells were engrafted in NSG mice to develop a mouse model of human T ALL, as indicated by the presence of mCherry $^{+}$cells in the peripheral blood by day 21 after engraftment (Extended Data Fig. 4d,e and g), and body weight loss, bone marrow invasion and marked splenomegaly by day 35 after engraftment (Extended Data Fig. 4h,i). We then set up the adoptive transfer of $\mathrm{CFSE}^{+}$p21TD-Mo or Co.TD-Mo, which did not induce any toxic effects (body and spleen weights; Extended Data Fig. 5a,b). p21TD-Mo or Co.TD-Mo-derived $\mathrm{CFSE}^{+} \mathrm{MDMs}$ were equally distributed in the bone marrow and the spleen of NSG mice, without being detected in peripheral blood or liver (Extended Data Fig. 5c-e). We transferred genetically engineered $\mathrm{CFSE}^{+}$p21TD-Mo or Co.TD-Mo into NSG mice that were simultaneously engrafted with MOLT4 $4^{+}$mCherry cells (Fig. 3a). Interestingly, the adoptive 
transfer of p21TD-Mo prevented body weight loss (Fig. 3b,c) and splenomegaly development (Fig. 3d,e) in mCherry ${ }^{+}$MOLT4-engrafted NSG mice. These clinical parameters were associated with a significant reduction of the leukemic burden in the peripheral blood, the bone marrow, the spleen and the liver of p21TD-Mo-treated mice, compared with Co.TD-Mo mice (Fig. 3f-j and Extended Data Fig. 5f). Consistently, a significant increase in survival was also observed in p21TD-Mo-treated leukemic mice (Fig. 3k). Altogether, these results demonstrated that the adoptive transfer of p21TD-Mo strongly reduced progression of leukemia.

To decipher the biological mechanisms involved in the beneficial effect of p21TD-Mo, mCherry ${ }^{+}$MOLT4 engrafted NSG mice (obtained as shown in Fig. 3a) were treated 21 days after the adoptive transfer of p21TD-Mo or Co.TD-Mo with liposomes containing or not clodronate. After 24 hours of treatment, clodronate selectively depleted p21TD-Mo or Co.TDMo-derived $\mathrm{CFSE}^{+}$macrophages (Extended Data Fig. 6a-c) and strongly reduced the survival of p21TD-Mo-treated NSG mice (Fig. 31). These results further demonstrate the key role of p21TD-Mo-derived macrophages in the inhibition of leukemia progression. To address in vivo the impact of $\mathrm{p} 21$-mediated SIRP $\alpha$ repression on disease regression, $\mathrm{p} 21 \mathrm{TD}-\mathrm{Mo}$, SIRP $\alpha \mathrm{TD}-$ Mo, p21+SIRP $\alpha$ TD-Mo or Co.TD-Mo were engineered (as shown in Fig. 2p) and transferred into NSG mice that were engrafted with $\mathrm{mCherry}^{+}$MOLT4 cells (Fig. 3a). As expected, while p21TD-Mo treated NSG mice lived longer, a significant decrease in survival of mice that received SIRP $\alpha$ TD-Mo was observed (Fig. 3m). In agreement with previous results (Fig. 2q,r), exogenous expression of a SIRP $\alpha$ cDNA that is resistant to $\mathrm{p} 21$ repression into $\mathrm{p} 21 \mathrm{TD}-$ Mo abrogated the positive effect of engineered p21TD-Mo transfer on mouse survival (Fig. $3 \mathrm{~m}$ ), further demonstrating the role of $\mathrm{p} 21$-mediated SIRP $\alpha$ repression in regulation of MDM function. The decreased survival of mice after depletion of Co.TD-Mo-derived macrophages with clodronate-containing liposomes (Fig. 31) and adoptive transfer of SIRPaTD-Mo (Fig. 
bioRxiv preprint doi: https://doi.org/10.1101/2022.01.18.476736; this version posted January $20,2022$. The copyright holder for this preprint (which was not certified by peer review) is the author/funder, who has granted bioRxiv a license to display the preprint in perpetuity. It is made available under aCC-BY-NC-ND 4.0 International license.

$3 \mathrm{~m}$ ) confirmed our in vitro results (Figs. 1 and 2), and demonstrated that lentiviral transduction of p21 potentiates the intrinsic capacity of anti-inflammatory macrophages to engulf leukemic cells in vivo.

Considering the pro-inflammatory fate of Phago ${ }^{+}$MDMs detected in vitro (Fig. 1), we sought to investigate its occurrence in vivo and its relevance for p21TD-Mo-based therapy. Twentyone days after the adoptive transfer of engineered $\mathrm{CFSE}^{+}$monocytes, $\mathrm{CFSE}^{+} \mathrm{Co}$.TD-Mo or p21TD-Mo-derived macrophages engulfing mCherry ${ }^{+}$MOLT4 cells were detected in the spleen of treated mice (Fig. 3n). More importantly, flow cytometry analysis of FACS-sorted non-phagocytic $\mathrm{CFSE}^{+}$(Phago ${ }^{-}$) or phagocytic $\left(\mathrm{Phago}^{+}\right) \mathrm{CFSE}^{+} \mathrm{mCherry}^{+} \mathrm{MDMs}$ from the spleen and the bone marrow of treated mice showed that Phago ${ }^{+} \mathrm{MDMs}$ decreased the membrane expression of CD163 scavenger receptor, compared with Phago`MDMs (Fig. 3o), thus confirming that in vivo, phagocytosis of leukemic cells promoted activation of MDMs toward a pro-inflammatory phenotype.

Given the key role of IFN $\gamma$ secretion by Phago ${ }^{+} \mathrm{MDMs}$ in the in vitro pro-inflammatory reprogramming of bystander Phago ${ }^{-M D M s}$ (Fig. 1), p21TD-Mo transferred NSG mice that were engrafted with mCherry ${ }^{+}$MOLT4 cells (Fig. 3a) were treated with anti-human IFN $\gamma($ hIFN $\gamma)$ blocking antibodies 15 days after monocyte transfer and analyzed for survival. Treatment with anti-hIFN $\gamma$ blocking antibodies strongly reversed the increased survival of mice that received p21TD-Mo (Fig. 3p), compared with controls. These results indicate that p21TD-Mo-based cellular therapy drives the engraftment of p21-transduced phagocytes, which besides directing the elimination of leukemic cells, triggers the secretion of the proinflammatory cytokine IFN $\gamma$ and supports the pro-inflammatory reprogramming of macrophages, which in turn participates in regression of leukemia.

To further explore the therapeutic effect of p21TD-Mo based cellular therapy, we treated NSG mice engrafted with patient-derived T-ALL cells (Extended Data Table 3), including 
bioRxiv preprint doi: https://doi.org/10.1101/2022.01.18.476736; this version posted January 20,2022 . The copyright holder for this preprint (which was not certified by peer review) is the author/funder, who has granted bioRxiv a license to display the preprint in perpetuity. It is made available under aCC-BY-NC-ND 4.0 International license.

two patient-derived xenograft models derived from the same patient at diagnosis (PDX\#1) and at relapse (PDX\#2) (Fig. 4a and Extended Data Fig. 7a-f). The adoptive transfer of p21TD-Mo significantly increased the survival of T-ALL PDX engrafted mice, compared with control mice treated with Co.TD-Mo (Fig. 4b-d). Moreover, the adoptive transfer of p21TD-Mo-based cellular therapy remained effective in mice engrafted with T-ALL cells at relapse. Altogether, these results support the translational potential of the therapeutic induction of p21-mediated tumor phagocytosis for treatment of T ALL.

\section{Discussion}

Taken together, our findings demonstrated that macrophage-expressed p21 is responsible for the pro-inflammatory activation of macrophages through the induction of tumor phagocytosis. Our findings provide direct genetic and functional evidence that macrophage-expressed p21 is a key regulator of leukemic cell phagocytosis by repressing the transcription of the inhibitory receptor of phagocytosis, SIRPa. After degradation of engulfed cells, phagocytic macrophages undergo pro-inflammatory activation and, through the secretion of IFN $\gamma$, convert surrounding anti-inflammatory macrophages into pro-inflammatory cells. Supporting the translational potential of our findings, the adoptive transfer of p21TD-Mo into mouse models of human leukemia cells leads, after their differentiation into TAMs in the spleen and bone marrow of treated mice, to phagocytosis of leukemic cells and the pro-inflammatory reprogramming of engineered TAMs. The p21-initiated, SIRP $\alpha$-repressed, phagocytosisguided, IFN $\gamma$-dependent pro-inflammatory macrophage activation of TAMs strongly reduces leukemic burden and prolongs mouse survival. Our findings uncover a novel cellular mechanism to direct the killing of leukemic cells and harness anti-tumor innate immunity in a way that could be targeted for cellular therapy against leukemia. Our findings also identify $\operatorname{SIRP} \alpha$ as a new target of transcriptional co-repressor $\mathrm{p} 21^{16,28,29}$. Future studies will identify 
the upstream and downstream effectors of $\mathrm{p} 21$ that enable $\mathrm{p} 21$ binding to SIRP $\alpha$ promoter and contribute to the repression of SIRP $\alpha$ transcriptional activity. In addition to the welldemonstrated release of IFN $\gamma$ by $\mathrm{CD}^{+}{ }^{\mathrm{T}}$ cells, $\mathrm{NK}$ cells and activated macrophages ${ }^{30}$, our results on the secretion of IFN $\gamma$ by phagocytic macrophages after leukemic cell degradation supports the notion that the accumulation in the tumor microenvironment of p21TD-Moderived macrophages with enhanced abilities to engulf leukemic cells and to trigger in situ the pro-inflammatory reprogramming of TAMs, could be an attractive alternative to overcome tumor immune evasion strategies ${ }^{3}$. Our findings also support the hypothesis that, in syngeneic immunocompetent murine models of leukemia, the effectiveness of p21TD-Mo-based cellular therapy would be increased, since phagocytic macrophages in the tumor microenvironment would activate, besides bystander macrophages, other host immune cells to support antitumor $\mathrm{T}$ cell priming and favor an adaptive anti-tumor immune response.

The therapeutic feasibility and safety of autologous macrophage-based cell therapy was previously shown ${ }^{31,32}$. However, genetic engineering of primary myeloid cells with clinically approved vectors such as self-inactived human immunodeficiency virus 1 (HIV-1)-based lentivirus remains for a long time a major difficulty ${ }^{32}$. In this study, we circumvent the resistance of primary monocytes and macrophages to lentiviral transduction by co-transducing p21-expressing lentiviral vector with viral like particles containing Vpx protein, which was shown to degrade SAMHD1 viral restriction factor without affecting p21 expression ${ }^{16}$, and thus enables to evaluate the potential of p21TD-Mo-based cellular therapy. Adoptive transfer of p21TD-Mo would represent a broad-spectrum therapy for leukemia because it could enhance the macrophage capacity for phagocytosis without affecting antigen pressure selection, which could induce the emergence of clonal resistance ${ }^{33}$. Finally, considering the current difficulties in eradicating acute leukemia, the adoptive transfer of p21TD-Mo should 
bioRxiv preprint doi: https://doi.org/10.1101/2022.01.18.476736; this version posted January 20,2022 . The copyright holder for this preprint (which was not certified by peer review) is the author/funder, who has granted bioRxiv a license to display the preprint in perpetuity. It is made available under aCC-BY-NC-ND 4.0 International license.

be considered as a novel strategy that could complement commonly used chemotherapeutic approaches. 


\section{Methods}

Primary cells and cell lines. Monocytes, MDMs and PBLs were obtained and differentiated as previously described ${ }^{16,34}$, from peripheral blood mononuclear cells (PBMCs) of buffy coats of healthy donors from French blood bank (Etablissement Français du Sang) in accordance with French law and with written informed consent of each donor. Monocytes were isolated from PBMCs by adherence to the plastic in macrophages medium (MM) (RPMI supplemented with $200 \mathrm{mM}$ L-glutamine, $100 \mathrm{U} / \mathrm{ml}$ of penicillin, $100 \mu \mathrm{g} / \mathrm{ml}$ streptomycin, 10 mM HEPES, $10 \mathrm{mM}$ sodium pyruvate, $50 \mu \mathrm{M} \beta$-mercaptoethanol, $1 \%$ minimum essential medium vitamins, $1 \%$ non-essential amino acids, all from Gibco) containing $2 \%$ (vol/vol) of heat inactivated (HI, for $1 \mathrm{~h}$ at $56^{\circ} \mathrm{C}$ ) human $\mathrm{AB}$ serum (hABS) (Sigma, \#H3667). After extensive washings with DPBS (Gibco, \#14190-094) to eliminate non-adherent cells, monocytes were incubated overnight in MM medium containing 10\% $\mathrm{HI}$ hABS before in vitro differentiation or with $2 \% \mathrm{HI}$ fetal bovine serum (FBS) before genetic engineering and/or adoptive transfer. Monocyte purity was analyzed by FACS and revealed that 90 to 96\% cells expressed hCD11b and hCD14 and did not express hCD56 (NK cells), hCD3 (T cells) and hCD20 (B cells) markers. For differentiation into MDMs, monocytes were cultured for 6 to 7 days in hydrophobic Teflon dishes (Lumox, \#94.6077.305) in MM containing 20\% HI hABS yielding adherent non-proliferating cells expressing 90-96\% macrophage (hCD11b, hCD14, hCD71) and M2-like (hCD163 and hCD206) markers. MDMs were then cultured in MM containing $10 \%$ of $\mathrm{HI}$ FBS at $1 \times 10^{6} / \mathrm{ml}$ for experiments. Isolation, PHA-P/IL2 activation and culture of PBLs were performed as previously described ${ }^{34}$. Jurkat, MOLT4, CEM, HEL and K562 cells were all from American Type Culture Collection (ATCC) and cultured in RPMI with 10\% HI FBS except for K562 (grown in IMDM (Gibco, \#21980-032) with 10\% 
bioRxiv preprint doi: https://doi.org/10.1101/2022.01.18.476736; this version posted January $20,2022$. The copyright holder for this preprint (which was not certified by peer review) is the author/funder, who has granted bioRxiv a license to display the preprint in perpetuity. It is made available under aCC-BY-NC-ND 4.0 International license.

HI FBS. For phagocytosis assays, all target cells were checked for freedom from mycoplasma contamination and were co-cultured with MDMs in MM with $10 \% \mathrm{HI}$ FBS.

Patient samples. Peripheral blood (PB) and bone marrow (BM) samples from AML patients (Extended Data Table 1) were prospectively collected after the obtention of informed consent according to the Declaration of Helsinki in the context of MYELOMONO2 study of Groupe Francophone des Myelodysplasies and approval by ethical committee authorizations (CCTIR $\mathrm{N}^{\circ}$ 14-266 and CNIL N914283). Mononucleated cells from PB or BM were then enriched for $\mathrm{CD} 4^{+}$cells on the AutoMacs system using human CD34 MicroBead kit (Miltenyi Biotec, \#130-046-702) according to manufacturer's instructions. The CD34 cell purity was checked by FACS and cells were cultured in IMDM with 10\% HI FBS supplemented with human cytokine and growth factor cocktail from Peprotech (hTPO (\#300-18) (10 ng/ml), hSCF (\#300-07) (25 ng/ml), hIL3 (\#200-03) (10 ng/ml), hIL6 (\#200-06) (10 ng/ml), hFlt-3 (\#AF300-19) (10 ng/ml)) for at least three days before phagocytosis assays. T-ALL PDXs samples were obtained as previously described ${ }^{35}$.

Plasmids, lentiviral vectors and transductions. For genetic engineering of monocytes, MDMs and MOLT4 cells, self-inactivated (SIN) lentiviral vectors were used. p21 cDNA was cloned in pAIP lentiviral vector ${ }^{36}$ under SFFVp promoter and SIRP $\alpha$ cDNA was cloned in pRRL-EF1-PGK-GFP lentiviral vector under EF1 promoter. mCherry cDNA was cloned in pRRL lentiviral vector under EF1 promoter for the establishment of mCherry ${ }^{+}$MOLT4 stable cell line. SIRPA 2 promoter sequence (EP026655) was identified from Eukaryotic Promoter Database (EPD) to be expressed in human primary monocytes and macrophages, was fused to luciferase (Luc) reporter gene and cloned in pRRL-EF1-PGK-GFP lentiviral after the insertion of three stop codons at the 3' end of E2F1 promoter. The initiator motif of SIRPA 2 
promoter is at $-530 \mathrm{bp}$ before transcription starting site (TSS) of SIRP $\alpha$ gene. Controls (AIP or RRL-EF1-PGK-GFP) or gene-encoding (AIP-p21, RRL-EF1-SIRP $\alpha$-PGK-GFP, RRLEF1-3xstop codons-SIRPA 2-Luc-PGK-GFP or RRL-mCherry) lentiviral vectors were produced by transfecting $5 \times 10^{6}$ HEK293T cells on T150 plate in $10 \mathrm{ml}$ Opti-mem medium (Gibco, \#31985-070) (containing 2\% HI FBS and $100 \mathrm{U} / \mathrm{ml}$ penicillin, $100 \mu \mathrm{g} / \mathrm{ml}$ streptomycin) with $4 \mu \mathrm{g}$ pDM2-VSV-G, $10 \mu \mathrm{g} \mathrm{p} \Delta 8.91$ packaging and $8 \mu \mathrm{g}$ lentiviral vector plasmid using Fugene (Promega, \#E2312) according manufacturer's instructions. Cell supernatants were removed after $24 \mathrm{~h}$ transfection and replaced by fresh $10 \mathrm{ml}$ Opti-mem medium (containing 2\% HI FBS and $100 \mathrm{U} / \mathrm{ml}$ penicillin, $100 \mu \mathrm{g} / \mathrm{ml}$ streptomycin) for additional $48 \mathrm{~h}$. Then, cell supernatant was harvested and filtered through a $0.45 \mu \mathrm{m}$ pore size filter. Viral stocks were quantified for viral CAp24 content by ELISA (Perkin Elmer, \# NEK050A) and by qPCR quantification of lentiviral integrated copies in human genome of MDMs as previously described ${ }^{34,37}$. Viral like particles containing Vpx protein (VLPs-Vpx ${ }^{+}$)

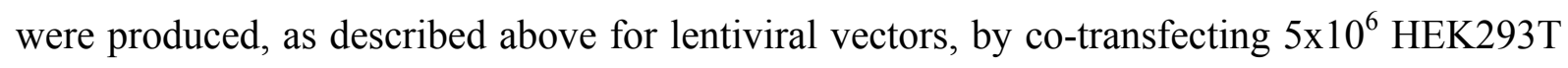
cells with $4 \mu \mathrm{g} \mathrm{pSIV3}{ }^{+}\left(\mathrm{Vpx}^{+}\right)$(kindly provided by A. Cimarelli, ENS Lyon) and $4 \mu \mathrm{g}$ pDM2VSV-G. Monocytes $\left(10^{7}\right)$ or MDM $\left(10^{6}\right)$ were treated for $1 \mathrm{~h}$ at $37^{\circ} \mathrm{C}$ with $1 \mathrm{ml}$ of VLPs$\mathrm{VPX}^{+}$containing $5 \mu \mathrm{g} / \mathrm{ml}$ polybrene (Sigma, \#H9268) for SAMHD1 degradation ${ }^{16,37}$ before the addition of $20 \mu \mathrm{g}$ CAp24 of each control or/and encoding-gene lentiviral vectors with 5 $\mu \mathrm{g} / \mathrm{ml}$ polybrene for $2 \mathrm{~h}$ transduction. After extensive washings with medium, monocytes were differentiated for 7d in MM with 20\% HI hABS before WB analysis and phagocytosis assays. MDMs were cultured 72h before mRNA qPCR analysis, luciferase activity using luciferase assay system (Promega, \#E1500) or chromatin immunoprecipitation (ChIP)-qPCR assays. While genetically engineered monocytes (Co.TD-Mo or p21TD-Mo) used for adoptive transfer in NSG mice were further incubated for 30 min with $1 \mu \mathrm{M}$ CellTracer CFSE cell proliferation kit (Invitrogen, \#C34554) before extensive washings with DPBS and intravenous (IV) 
injection of mice. MOLT4 cells $\left(5 \times 10^{6}\right)$ were transduced with $100 \mu \mathrm{g}$ CAp24 RRL-mCherry by $1 \mathrm{~h}$ spinoculation at $1200 \mathrm{~g}$ at $25^{\circ} \mathrm{C}$ and $1 \mathrm{~h}$ incubation at $37^{\circ} \mathrm{C}$. After $72 \mathrm{~h}$, MOLT4 cells expressing mCherry gene were sorted by FACS and cultured in RPMI with $10 \%$ HI FBS.

\section{In vitro macrophage-mediated phagocytosis assays, sorting and functional assays with}

Phago ${ }^{-}$MDMs and Phago $^{+}$MDMs. For phagocytosis assays, MDMs $\left(0.125 \times 10^{6}\right.$ cells $)$ were let to adhere for $2 \mathrm{~h}$ in $125 \mu \mathrm{MM}$ with $10 \% \mathrm{HI}$ FBS in one well of 8-chamber tissue culture treated glass slide (Falcon, \#354118), labeled with $20 \mu \mathrm{M}$ cell tracker green CMFDA (Invitrogen, $\# \mathrm{C} 2925)$ for $1 \mathrm{~h}$ at $37^{\circ} \mathrm{C}$ and washed three times with $1 \mathrm{ml}$ of medium before coculture with target cells. Leukemic, PBL or CD34 ${ }^{+}$AML cells were incubated at $1 \times 10^{6} / \mathrm{ml}$ in RPMI with 10\% HI FBS containing $100 \mu \mathrm{M}$ ZVAD (Bachem, \#4027403.0005) and $10 \mu \mathrm{M}$ cell tracker orange CMTMR (Invitrogen, \#C2927) for $1 \mathrm{~h}$ at $37^{\circ} \mathrm{C}$. After extensive washings, $\mathrm{CMTMR}^{+}$target cells $\left(0.125 \times 10^{6}\right.$ cells $)$ were added to adherent $\mathrm{CMFDA}^{+}$MDMs $(1: 1$ ratio $)$ at $1 \times 10^{6}$ cells $/ \mathrm{ml}$ in $\mathrm{MM}$ with $10 \% \mathrm{HI}$ FBS for $8 \mathrm{~h}$ co-culture in the presence of ZVAD (100 $\mu \mathrm{M})$, Y27632 $(30 \mu \mathrm{M})$ (Tocris, \#1254), human recombinant Annexin V (5 $\mu \mathrm{g} / \mathrm{ml})$ (Invitrogen, \#BMS306) or with the same amounts of their respective solvent (DMSO or H2O) or IgG1 isotype controls (Abcam, \#ab280974). MDMs were pre-treated with Y27632 (30 $\mu \mathrm{M}$, 24h), PMA (30 ng/ml, 32h) (Sigma, \#P1585), MS275 (1 $\mu \mathrm{M}, 32 \mathrm{~h})$ (Enzo, \#ALX-270-378M001) or with same volume amount of DMSO before co-cultures with target cells. MDMs were also let to adhere on wells precoated with $100 \mathrm{mg}$ intravenous human immunoglobulin (IVIg) (CSL Behring) for 24h before co-culture. Silenced MDMs for p21 (sip21) and its control (siCo.) were co-cultured with target cells or with pHrodo green bacterial E. coli bioparticles (according manufacturer's instructions) (Life technologies, \#P35366) at 24h or 48h, respectively, after siRNA transfection. Jurkat or CD34 ${ }^{+}$AML cells were pretreated with $50 \mu \mathrm{M}$ cisplatin (CDDP) (Mylan) for 24h to induce apoptosis before co-culture with MDMs. 
After $8 \mathrm{~h}$ of co-culture, the cell supernatant (which contains target cells that were not internalized by MDMs) was removed and MDMs were washed extensively and fixed 5 min with 2\% PFA before confocal microscopy analysis. For the FACS sorting of Phago`MDMs and Phago ${ }^{+}$MDMs, MDMs $\left(10 \times 10^{6}\right)$ resuspended at $1 \times 10^{6} / \mathrm{ml}$ in MM with $10 \%$ HI FBS were labeled with $2.5 \mu \mathrm{M}$ CMFDA for $1 \mathrm{~h}$ at $37^{\circ} \mathrm{C}$ in $50 \mathrm{ml}$ falcon tube. Target cells (MOLT4 or $\left.\mathrm{CD} 34^{+} \mathrm{AML}\right)\left(10 \times 10^{6}\right)$ were resuspended at $1 \times 10^{6} / \mathrm{ml}$ in RPMI with $10 \%$ HI FBS containing $100 \mu \mathrm{M}$ ZVAD for staining with $1.25 \mu \mathrm{M}$ CMTMR for $1 \mathrm{~h}$ at $37^{\circ} \mathrm{C}$ in $50 \mathrm{ml}$ falcon tube. After extensive washings with medium, MDMs and target cells (1:1 ratio) were co-cultured in 50 $\mathrm{ml}$ Falcon tube at $1 \times 10^{6} / \mathrm{ml}$ in $\mathrm{MM}$ with $10 \% \mathrm{HI}$ FBS for $2 \mathrm{~h}$ at $37^{\circ} \mathrm{C}$. Then, $\mathrm{Phago}^{+}$ $\left(\mathrm{CMFDA}^{+} \mathrm{CMTMR}^{+}\right) \mathrm{MDMs}$ and Phago $\left(\mathrm{CMFDA}^{+}\right) \mathrm{MDMs}$ were sorted by FACS. The purity of sorted populations was checked with FACS. Phago ${ }^{+}$MDMs and Phago MDMs (at least $0.01 \times 10^{6}$ each) were then let to adhere on wells of 8 -chamber tissue culture treated glass slides for $2 \mathrm{~h}$ and $96 \mathrm{~h}$ before $2 \%$ PFA fixation and confocal microscopy analysis of target cell internalization by MDMs and their corresponding degradation, respectively. For gene expression microarray analysis, CD163 membrane expression by FACS, cell supernatant analysis by proteome profiler human cytokine panel A array (according manufacturer's instructions) (RD, \#ARY005), Phago ${ }^{+}$MDMs and Phago-MDMs (at least $0.1 \times 10^{6}$ each) were cultured in MM with 10\% HI FBS for 96h. For WB analysis, Phago ${ }^{+}$MDMs and Phago MDMs were cultured 7d. For study of bystander activation of macrophages, $2 \mathrm{~h}$ after FACS sorting, Phago MDMs $\left(0.1 \times 10^{6}\right.$ in $1 \mathrm{ml}$ of MM with $10 \%$ HI FBS $)$ were adhered on 24 well plates in bottom chambers of Phago-MDMs or Phago ${ }^{+}$MDMs $\left(0.1 \times 10^{6}\right.$ in $\left.200 \mu l\right)$ adhered on $0.4 \mu \mathrm{m}$ pore membranes of transwell cell culture inserts (Falcon, \#353095) for $15 \mathrm{~d}$ of coculture in the presence of $1 \mu \mathrm{g} / \mathrm{ml}$ anti-hIFN $\gamma$ antibody clone 25718 (RD, \#MAB285) or mouse IgG2A control isotype (RD, \#MAB003). Phago-MDMs at bottom chambers were then analysed by WB. 


\section{Adoptive transfer of lentivirus-mediated genetically engineered human monocytes into}

human T-ALL mouse models. Mice studies were performed in accordance with protocols approved by the French Ethical Committee CEEA26 and following recommendations of proper use and care of animal experimentation. Mice experiments were performed using 6- to 8- weeks old female and male NOD.Cg-Prkdc ${ }^{\text {scid }} I l 2 r g^{t m l W j l} / \mathrm{SzJ}$ (NSG) immune-deficient mice purchased from Charles River Laboratories, maintained in specific pathogen-free conditions and randomized for homogenous mice body weight groups (20g to $23 \mathrm{~g}$ ) before experiments. Intravenous (IV) injections were performed with $200 \mu \mathrm{l}$ cell suspension in DPBS/mouse via retro-orbital sinus under isoflurane gas anesthesia. For the assessment of the in vivo differentiation of human monocytes into macrophages, monocytes (Mo) $\left(5 \times 10^{6} /\right.$ mouse) were labeled with $1 \mu \mathrm{M}$ CFSE for $30 \mathrm{~min}$ at $37^{\circ} \mathrm{C}$, extensively washed and IV injected into NSG mice $24 \mathrm{~h}$ after their 1 Gray (1 Gy) total body irradiation (TBI) with X-RAD-320 irradiator (Precision X Ray). Seven days after monocyte transfer, NSG mice were sacrificed and sorted $\mathrm{CFSE}^{+}$cells from dissociated bone marrow (BM) and spleen cells were analyzed for human M2 like macrophage markers (hCD11b, hCD14 and hCD163). For the establishment of the mouse model of human T-ALL, FACS-sorted mCherry ${ }^{+}$MOLT4 cells $\left(10^{6} / \mathrm{mouse}\right)$, obtained by RRL-mCherry lentiviral vector transduction as described above, were IV injected in NSG mice and then after $30 \mathrm{~d}, \mathrm{mCherry}^{+}$leukemic cells which engrafted BM were sorted by FACS and cultured in RPMI with 10\% HI FBS for in vitro macrophage-mediated phagocytosis assays and mice injections. To characterize leukemia progression, mCherry ${ }^{+} \mathrm{MOLT} 4$ cells $\left(10^{6} /\right.$ mouse) were IV injected in 1 Gy TBI NSG mice $7 \mathrm{~d}$ after irradiation. The percentage of $\mathrm{mCD} 45^{-} \mathrm{hCD} 45^{+} \mathrm{mCherry}^{+}$cells detected in the peripheral blood (PB) was determined every week. After 35d, mice were sacrificed and the presence of leukemic cells in BM and spleen were analyzed by FACS. To characterize the engraftment of genetically engineered 
monocytes into mice, CFSE-labeled Co.TD-Mo or p21TD-Mo $\left(5 \times 10^{6} /\right.$ mouse $)$ were IV injected in 1 Gy TBI NSG mice and sacrificed after 21d. The presence of $\mathrm{CFSE}^{+}$derived macrophages in $\mathrm{PB}, \mathrm{BM}$, spleen and liver were determined by FACS and confocal microscopy. For the prophylactic adoptive transfer of monocytes, 1 Gy TBI NSG mice were IV injected with CFSE-labeled Co.TD-Mo or p21TD-Mo $\left(5 \times 10^{6} /\right.$ mouse $)$ and after $7 \mathrm{~d}$ were IV injected with $\mathrm{mCherry}{ }^{+}$MOLT4 cells $\left(10^{6} /\right.$ mouse $)$. Mice were then analyzed for overall survival or sacrificed at $21 \mathrm{~d}$ to determine leukemia burden (in PB, BM, spleen and liver by FACS and confocal microscopy). In vivo pro-inflammatory activation of engineered macrophages was also determined by sorting phagocytic ( $\mathrm{CFSE}^{+} \mathrm{mCherry}^{+}$cells) and single $\left(\mathrm{CFSE}^{+}\right)$Co.TD or p21TD-derived macrophages from BM and spleen cells and analyzing hCD163 membrane expression by FACS. To determine impacts of Co.TD-Mo or p21TD-Moderived macrophages and their related hIFN $\gamma$ secretions on the overall survival of mice, treated NSG mice were also IV injected with of $200 \mu 1 /$ mouse of clodronate- or control PBScontaining liposomes (Liposoma, \#CP-005-005) or intraperitoneally injected with 100 $\mu \mathrm{g} /$ mouse IgG control isotype (RD, \#MAB003) or anti-hIFN $\gamma$ antibody (clone 25718; RD, \#MAB285), 21d or 15d after monocyte transfer, respectively. Clodronate-mediated depletion of CFSE-labeled Co.TD-Mo or p21TD-Mo-derived macrophages was assessed by FACS 24h after treatments. To study effects of $\mathrm{p} 21$-mediated SIRP $\alpha$ repression on the overall survival of engrafted mice, prophylactic monocyte adoptive transfer $\left(5 \times 10^{6} /\right.$ mouse $)$ was performed with genetically engineered Co.TD-Mo, p21TD-Mo, SIRP $\alpha$ TD-Mo or p21+SIRP $\alpha$ TD-Mo, which were transduced as described above with respectively equal amounts of AIP+RRL-PGk-GFP, AIP-p21+RRL-PGK-GFP, AIP+RRL-SIRP $\alpha$-PGK-GFP or AIP-p21+RRL-SIRP $\alpha-P G K-G F P$ lentiviral vectors. For curative approach, T-ALL PDX cells $\left(10^{5} /\right.$ mouse for PDX\#1 and PDX\#2 and $2 \times 10^{5} /$ mouse for PDX\#3) were IV injected in NSG mice. PDX cell engraftments were assessed at 21d (for PDX\#1 and PDX\#2) and 15d (for PDX\#3) by femoral BM sampling 
as previously described ${ }^{35}$ and FACS detection of hCD $45^{+} h C D 7^{+}$PDX cells. Then $1 \mathrm{~d}$ after BM sampling showing 40 to $70 \%$ PDX cell engraftment in BM, NSG mice were randomized to have homogenous groups for PDX engraftments, IV injected with Co.TD-Mo or p21TDMo $\left(5 \times 10^{6} /\right.$ mouse $)$ and monitored for overall survival.

Human macrophage knockdowns. MDM knockdowns were performed as we previously described ${ }^{16,34}$ using $50 \mathrm{nM}$ of non-targeting pool control siRNAs (UGGUUUACAUGUCGA CUAA, UGguUUACAUGUUGUGUGA, UGgUUUACAUGUUUUCUGA, UGGUUU $\begin{array}{lllllll}\text { ACAUGUUUUCCUA) } & \text { or } & \text { p21 } & \text { smart } & \text { pool } & \text { selected }\end{array}$ (AGACCAGCAUGACAGAUUU), all purchased from Dharmacon. MDMs were silenced for p21 for $24 \mathrm{~h}$ before WB or co-cultures with target cells.

Gene expression. Determination of $\mathrm{p} 21$ and SIRP $\alpha$ mRNAs by RT-qPCR were performed as we previously described ${ }^{16,38}$ using TaqMan gene expression predesigned probes for SIRP $\alpha$ (Hs00757426 S1), p21 (Hs00355782 m1) and GAPDH (Hs02758991 g1). Gene expression analysis of Phago MDMs and Phago ${ }^{+}$MDMs were performed with Agilent ${ }^{\circledR}$ SurePrint G3 Human GE 8x60K Microarray (Agilent Technologies, AMADID 28004) with two technical replicates for each sample. Data are determined for each analyzed donor by the mean of two technical replicates of $\log 2$ fold change (FC) of gene intensity ratio of $\mathrm{Phago}^{+} \mathrm{MDMs} / \mathrm{Phago}^{-}$ MDMs. To produce a comprehensive analysis of modulated genes for their ability to regulate anti-inflammatory or pro-inflammatory processes or to be modulated by IFN $\gamma$-dependent signaling pathways or treatments, a systematic literature search with Pubmed science web was performed using key words "the gene name AND macrophages" and " the gene name AND interferon gamma" (Extended Data Table 2). 
Chromatin immunoprecipitation (ChIP)-qPCR assays. Chromatin immunoprecipitation assays were performed with MDMs using Chip assay kit (Millipore, \#17-295) and according to manufacturer's instructions. Briefly, cross-linked cell chromatins were sheared by sonication during $10 \mathrm{~min}$ at $40 \mathrm{~W}$ (duty factor: $20 \%$; peak incident power: 200; cycles per burst: 200) by Covaris S220 (Woodingdean, UK). Chromatins were then immunoprecipitated with $20 \mu \mathrm{g}$ of anti-p21 Waf1/Cip1 (12D1) antibodies (Cell signaling, \#2947) or with equal amount of rabbit IgG control isotype. DNA-bound to chromatin immunoprecipitates were finally eluted and analyzed by qPCR using Power SYBER Green PCR Master Mix (Applied Biosystems\#4367659) for the detection of SIRP $\alpha$ promoter sequence (SIRPA 2) with specific primers SIRPA 2 forward (5'CCACCGAGACACCTGGCCAG3') and SIRPA 2 reverse (5'AAGTGAACGCAGGGGGAAGG3'). Specificity of promoter sequence detection was checked by negative qPCR controls which target unrelated promoter sequence at $-2000 \mathrm{bp}$ upstream of 5 ' end of SIRPA 2 promoter using Untarget-SIRPA 2 forward (5'CCGTGGGTCTCAATGGCTTC3') and Untarget-SIRPA 2 reverse (5'GGGGGATTAGGAAACTGGAG3') primers. The normalization of DNA amount was performed by quantifying albumin gene copies with qPCR using human genomic DNA (20 ng/ $\mu \mathrm{l}$ ) standard (Roche, \#11691112001) as we previously described ${ }^{16}$.

Western blot. WBs were performed as we previously described ${ }^{16,38}$ using anti-p21 Waf1/Cip1 (12D1) (\#2947), anti-Myosin Light Chain 2 (MLC2) (\#3672), anti-Phospho (Ser19) Myosin light chain 2 (\#3671), anti- $\alpha$ Tubulin (\#3873) and anti- $\alpha / \beta$-Tubulin (\#2148) antibodies from Cell Signaling, anti-IL8 (\#ab106350), anti-IRF5 (\#ab21689), anti-ILb (\#ab2105) and anti-iNOS (\#ab3523) antibodies from Abcam, anti-IL6 antibody (RD, \#AB206-NA), anti-SIRPa antibody (Invitrogen, \#PA1-30537) and anti-GAPDH antibody (Millipore, \#MAB374). 
Flow cytometry. Cell samples were analyzed by FACS using BD LSR2 or BD LSRFortessa (BD Biosciences) and sorted using BD FACSAria III (BD Biosciences). Cell stainings were performed in DPBS containing 2\% (for cultured cells) or 5\% (for mouse cells) HI FBS at $4{ }^{\circ} \mathrm{C}$ for $2 \mathrm{~h}$ incubation with 1:100 antibody dilution. For blood samples, red cells were lysed with ACK buffer before incubations with antibodies and/or FACS analysis for mCherry ${ }^{+}$or $\mathrm{CFSE}^{+}$ cells. Mouse cell samples were filtered through $100 \mu \mathrm{m}$ pore size membrane filters before FACS staining and analyses. Antibodies used were anti-hCD14 clone 61D3 (eBioscience, \#12-0149-109 42), anti-hCD11b clone ICRF44 (\#301342), anti-hCD34 Clone 561 (\#343606), anti-hCD7 Clone CD7-6B7 (\#343120) from Biolegend and anti-hCD163 clone GHI/61 (\#562669), anti-hCD71 (\#555537), anti-hCD206 (\#551135), anti-hCD56 clone B159 (\#560916), anti-hCD3 (\#555339), anti-hCD20 (\#559776), anti-mCD45 clone 30-F11 (\#560501), anti-hCD45 clone HI30 (\#555485) from BD Pharmingen. Membrane expression of CD163 was determined by mean fluorescence intensities (MFI).

Confocal microscopy. After fixation, co-cultures containing single $\mathrm{CMFDA}^{+} \mathrm{MDMs}$ and phagocytic $\mathrm{CMFDA}^{+} \mathrm{CMTMR}^{+} \mathrm{MDMs}$ were permeabilized with $0.1 \%$ triton in DPBS for 5 min at room temperature, extensively washed, incubated with DPBS containing $10 \%$ HI FBS and 1:1000 Hoechst 33342 (Invitrogen, \#H3570) for nuclear staining and mounted onto microscope cover slips with Fluoromount G (Southern Biotech, \#0100-01). Immunofluorescence staining with anti-LAMP2 antibody (Santa Cruz, \#sc-18822) and acquisitions by confocal microscopy (SP8, Leica) of fixed stained cells were performed as we previously described ${ }^{34}$. Percentages of phagocytosis were determined by dividing number of $\mathrm{CMFDA}^{+} \mathrm{CMTMR}^{+} \mathrm{MDMs}$ on total number of MDMs quantified on at least 5 fields containing at least $100 \mathrm{MDMs}$ of each glass well. For determination of cell surfaces and 
bioRxiv preprint doi: https://doi.org/10.1101/2022.01.18.476736; this version posted January $20,2022$. The copyright holder for this preprint (which was not certified by peer review) is the author/funder, who has granted bioRxiv a license to display the preprint in perpetuity. It is made available under aCC-BY-NC-ND 4.0 International license.

volumes, target cells were labeled with CMTMR at $10 \mu \mathrm{M}$ and 1:1000 Hoechst 33342 for 30 min at $37^{\circ} \mathrm{C}$, and live imaged in ibidi 8 well chamber slides (ibiTreat, \#80826) by confocal microscopy (SP8, Leica) with z-stacks $(0.22 \mu \mathrm{m}$ step) acquisitions covering from the top to the bottom of cells. After 3D constructions, cell volumes and surfaces were measured by Volocity software (Quorum Technologies). For detection of $\mathrm{CFSE}^{+}$and mCherry ${ }^{+}$cells engrafted in mice tissues, fresh intact pieces of spleen, liver or longitudinal cut femur BM were incubated in $500 \mu \mathrm{l} \mathrm{HI} \mathrm{FBS} \mathrm{containing} \mathrm{0.3 \%} \mathrm{triton} \mathrm{and} \mathrm{1:250} \mathrm{Hoechst} 33342$ for $12 \mathrm{~h}$ at $4^{\circ} \mathrm{C}$. Medium was then replaced with cold HI FBS with 1:250 Hoechst 33342 and conserved on ice up to confocal microscopy acquisition of each organ tissue in ibidi 8 well chamber slides. Mouse tissues (at least $2 \mathrm{~mm}^{2} /$ organ) were imaged by confocal microscopy (SP8, Leica) using 40x oil objective, hybrid detectors (pinhole airy: 0.6; pixel size: $284 \mathrm{~nm}$, surface of each image field surface is $290.62 \times 290.62 \mu \mathrm{m}^{2}$ ) at optimal optical sectioning (OOS) of 1 $\mu \mathrm{m}$. Organ cell layers were then 3D constructed by Imaris 5.7 software (Bitplane AG), and $\mathrm{CFSE}^{+}$and mCherry ${ }^{+}$cells were quantified and normalized to $10 \mathrm{~mm}^{2}$ of tissue surface.

Statistics. Statistical analysis was performed in GraphPad Prism 6.0 (GraphPad). Statistical tests, adjustments used for multiple comparisons, exact calculated $\mathrm{p}$-values and $\mathrm{n}$ size of each figure are indicated in figure legends. For all figures, statistical significances were given as *p $<0.05$ and $* * \mathrm{p}<0.01, * * * \mathrm{p}<0.001, * * * * \mathrm{p}<0.0001$ 


\section{References}

1. Mantovani, A., Marchesi, F., Malesci, A., Laghi, L. \& Allavena, P. Tumour-associated macrophages as treatment targets in oncology. Nat Rev Clin Oncol 14, 399-416, doi:10.1038/nrclinonc.2016.217 (2017).

2. Ruffell, B. \& Coussens, L. M. Macrophages and therapeutic resistance in cancer. Cancer Cell 27, 462-472, doi:10.1016/j.ccell.2015.02.015 (2015).

3. DeNardo, D. G. \& Ruffell, B. Macrophages as regulators of tumour immunity and immunotherapy. Nat Rev Immunol 19, 369-382, doi:10.1038/s41577-019-0127-6 (2019).

4. Russ, A. et al. Blocking "don't eat me" signal of CD47-SIRPalpha in hematological malignancies, an in-depth review. Blood Rev 32, 480-489, doi:10.1016/j.blre.2018.04.005 (2018).

5. Advani, R. et al. CD47 Blockade by Hu5F9-G4 and Rituximab in Non-Hodgkin's Lymphoma. N Engl J Med 379, 1711-1721, doi:10.1056/NEJMoa1807315 (2018).

6. Chen, J. et al. SLAMF7 is critical for phagocytosis of haematopoietic tumour cells via Mac-1 integrin. Nature 544, 493-497, doi:10.1038/nature22076 (2017).

7. Chao, M. P., Majeti, R. \& Weissman, I. L. Programmed cell removal: a new obstacle in the road to developing cancer. Nat Rev Cancer 12, 58-67, doi:10.1038/nrc3171 (2011).

8. Feng, M. et al. Programmed cell removal by calreticulin in tissue homeostasis and cancer. Nat Commun 9, 3194, doi:10.1038/s41467-018-05211-7 (2018).

9. Jaiswal, S. et al. CD47 is upregulated on circulating hematopoietic stem cells and leukemia cells to avoid phagocytosis. Cell 138, 271-285, doi:10.1016/j.cell.2009.05.046 (2009).

10. Gordon, S. R. et al. PD-1 expression by tumour-associated macrophages inhibits phagocytosis and tumour immunity. Nature 545, 495-499, doi:10.1038/nature22396 (2017).

11. Barkal, A. A. et al. CD24 signalling through macrophage Siglec-10 is a target for cancer immunotherapy. Nature 572, 392-396, doi:10.1038/s41586-019-1456-0 (2019).

12. Barkal, A. A. et al. Engagement of MHC class I by the inhibitory receptor LILRB1 suppresses macrophages and is a target of cancer immunotherapy. Nat Immunol 19, 76-84, doi:10.1038/s41590-017-0004-z (2018).

13. Tsai, R. K. \& Discher, D. E. Inhibition of "self" engulfment through deactivation of myosin-II at the phagocytic synapse between human cells. J Cell Biol 180, 989-1003, doi:10.1083/jcb.200708043 (2008).

14. Weiskopf, K. et al. Engineered SIRPalpha variants as immunotherapeutic adjuvants to anticancer antibodies. Science 341, 88-91, doi:10.1126/science.1238856 (2013). 
15. Theocharides, A. P. et al. Disruption of SIRPalpha signaling in macrophages eliminates human acute myeloid leukemia stem cells in xenografts. J Exp Med 209, 1883-1899, doi:10.1084/jem.20120502 (2012).

16. Allouch, A. et al. p21-mediated RNR2 repression restricts HIV-1 replication in macrophages by inhibiting dNTP biosynthesis pathway. Proc Natl Acad Sci US A 110, E3997-4006, doi:10.1073/pnas.1306719110 (2013).

17. Uribe-Querol, E. \& Rosales, C. Phagocytosis: Our Current Understanding of a Universal Biological Process. Front Immunol 11, 1066, doi:10.3389/fimmu.2020.01066 (2020).

18. Boada-Romero, E., Martinez, J., Heckmann, B. L. \& Green, D. R. The clearance of dead cells by efferocytosis. Nat Rev Mol Cell Biol 21, 398-414, doi:10.1038/s41580-020-0232-1 (2020).

19. Murray, P. J. \& Wynn, T. A. Protective and pathogenic functions of macrophage subsets. Nat Rev Immunol 11, 723-737, doi:10.1038/nri3073 (2011).

20. Duluc, D. et al. Interferon-gamma reverses the immunosuppressive and protumoral properties and prevents the generation of human tumor-associated macrophages. Int J Cancer 125, 367-373, doi:10.1002/ijc.24401 (2009).

21. Asada, M. et al. Apoptosis inhibitory activity of cytoplasmic p21(Cip1/WAF1) in monocytic differentiation. EMBO J 18, 1223-1234, doi:10.1093/emboj/18.5.1223 (1999).

22. Kramer, J. L., Baltathakis, I., Alcantara, O. S. \& Boldt, D. H. Differentiation of functional dendritic cells and macrophages from human peripheral blood monocyte precursors is dependent on expression of p21 (WAF1/CIP1) and requires iron. Br J Haematol 117, 727734, doi:10.1046/j.1365-2141.2002.03498.x (2002).

23. Comalada, M., Xaus, J., Sanchez, E., Valledor, A. F. \& Celada, A. Macrophage colonystimulating factor-, granulocyte-macrophage colony-stimulating factor-, or IL-3-dependent survival of macrophages, but not proliferation, requires the expression of p21(Wafl) through the phosphatidylinositol 3-kinase/Akt pathway. Eur $J$ Immunol 34, 2257-2267, doi:10.1002/eji.200425110 (2004).

24. Gazova, I. et al. The Transcriptional Network That Controls Growth Arrest and Macrophage Differentiation in the Human Myeloid Leukemia Cell Line THP-1. Front Cell Dev Biol 8, 498, doi:10.3389/fcell.2020.00498 (2020).

25. Schwaller, J. et al. Up-regulation of p21WAF1 expression in myeloid cells is activated by the protein kinase C pathway. Br J Cancer 76, 1554-1557, doi:10.1038/bjc.1997.595 (1997).

26. Rosato, R. R., Almenara, J. A. \& Grant, S. The histone deacetylase inhibitor MS-275 promotes differentiation or apoptosis in human leukemia cells through a process regulated by generation of reactive oxygen species and induction of p21CIP1/WAF1 1. Cancer Res 63, 3637-3645 (2003).

27. Veillette, A. \& Chen, J. SIRPalpha-CD47 Immune Checkpoint Blockade in Anticancer Therapy. Trends Immunol 39, 173-184, doi:10.1016/j.it.2017.12.005 (2018). 
28. Chang, B. D. et al. Effects of $\mathrm{p} 21 \mathrm{Waf1/Cip1/Sdi1}$ on cellular gene expression: implications for carcinogenesis, senescence, and age-related diseases. Proc Natl Acad Sci U S $A$ 97, 4291-4296, doi:10.1073/pnas.97.8.4291 (2000).

29. Perkins, N. D. Not Just a CDK Inhibitor: Regulation of Transcription by p21WAF1/CIP1/SDI1. Cell Cycle 1, 35-37, doi:10.4161/cc.1.1.98 (2014).

30. Darwich, L. et al. Secretion of interferon-gamma by human macrophages demonstrated at the single-cell level after costimulation with interleukin (IL)-12 plus IL-18. Immunology 126, 386-393, doi:10.1111/j.1365-2567.2008.02905.x (2009).

31. Burger, M. et al. The application of adjuvant autologous antravesical macrophage cell therapy vs. BCG in non-muscle invasive bladder cancer: a multicenter, randomized trial. $J$ Transl Med 8, 54, doi:10.1186/1479-5876-8-54 (2010).

32. Klichinsky, M. et al. Human chimeric antigen receptor macrophages for cancer immunotherapy. Nat Biotechnol 38, 947-953, doi:10.1038/s41587-020-0462-y (2020).

33. Blum, S., Martins, F. \& Lubbert, M. Immunotherapy in adult acute leukemia. Leuk Res 60, 63-73, doi:10.1016/j.leukres.2017.06.011 (2017).

34. Allouch, A. et al. SUGT1 controls susceptibility to HIV-1 infection by stabilizing microtubule plus-ends. Cell Death Differ 27, 3243-3257, doi:10.1038/s41418-020-0573-5 (2020).

35. Poglio, S. et al. Speed of leukemia development and genetic diversity in xenograft models of $\mathrm{T}$ cell acute lymphoblastic leukemia. Oncotarget 7, 41599-41611, doi:10.18632/oncotarget.9313 (2016).

36. Allouch, A. et al. The TRIM family protein KAP1 inhibits HIV-1 integration. Cell Host Microbe 9, 484-495, doi:10.1016/j.chom.2011.05.004 (2011).

37. Allouch, A. et al. Reply to Pauls et al.: p21 is a master regulator of HIV replication in macrophages through dNTP synthesis block. Proc Natl Acad Sci U S A 111, E1325-1326, doi:10.1073/pnas.1322699111 (2014).

38. Paoletti, A. et al. HIV-1 Envelope Overcomes NLRP3-Mediated Inhibition of F-Actin Polymerization for Viral Entry. Cell Rep 28, 3381-3394 e3387, doi:10.1016/j.celrep.2019.02.095 (2019). 
bioRxiv preprint doi: https://doi.org/10.1101/2022.01.18.476736; this version posted January $20,2022$. The copyright holder for this preprint (which was not certified by peer review) is the author/funder, who has granted bioRxiv a license to display the preprint in perpetuity. It is made available under aCC-BY-NC-ND 4.0 International license.

\section{Acknowledgements}

We gratefully acknowledge Prof. D. M. Ojcius for helpful scientific discussions, NH Theraguix for supporting our projects against cancer, and M. Morabito and L. Bencheikh for their technical support. This work has benefited from the facilities and expertise of the Imaging and Cytometry Platform (S. Salome-Desnoulez and T. Manoliu), Genomic and Bioinformatics Platforms (N. Droin and G. Meurice), UMS 3655 CNRS / US 23 INSERM. Gustave Roussy Cancer Campus Villejuif, France. This work was supported by funds from Agence Nationale de la Recherche (ANR-10-IBHU-0001, ANR-10-LABX33, ANR-11IDEX-003-01 and ANR Flash COVID-19 "MacCOV”), Fondation Gustave Roussy, Institut National du Cancer (INCA 9414), The SIRIC Stratified Oncology Cell DNA Repair and Tumor Immune Elimination (SOCRATE), Care network (directed by X. Mariette, Kremlin Bicêtre AP-HP) and Université Paris-Saclay (to J.-L. Perfettini) and The SIRIC Stratified Oncology Cell DNA Repair and Tumor Immune Elimination 2.0 (SOCRATE 2.0, INCADGOS-INSERM 12551) (to A. Allouch). 


\section{Author contributions}

J.-L.P. conducted the study. A.A. and J.-L.P. designed the study. A.A., L.V., Y.Z., S.Q.R. and

Y.L. performed experiments. J.C., D.S.-B., S.DB., E. S., F.L. and F.P. provided PDXs and AML samples. A.A., Y.L., F.P. and J.-L.P. analyzed the results. A.A. assembled the figures. A.A. and J.-L.P. wrote the initial draft. A.A., L.V., Y.Z., S.Q.R., Y.L. and J.C., D.S.-B., S.DB., E. S., F.L., F.P. and J.-L. P. provided advice and edited the initial draft. 
bioRxiv preprint doi: https://doi.org/10.1101/2022.01.18.476736; this version posted January $20,2022$. The copyright holder for this preprint (which was not certified by peer review) is the author/funder, who has granted bioRxiv a license to display the preprint in perpetuity. It is made available under aCC-BY-NC-ND 4.0 International license.

\section{Competing interests}

A.A. and J.-L.P. are listed as co-inventors on a patent application related to p21TD-Mo-based cellular therapy. J.-L.P. is founding member of Findimmune SAS, an Immuno-Oncology Biotech company. J.-L.P. disclosed research funding not related to this work from NH TherAguix SAS. 
bioRxiv preprint doi: https://doi.org/10.1101/2022.01.18.476736; this version posted January 20,2022 . The copyright holder for this preprint (which was not certified by peer review) is the author/funder, who has granted bioRxiv a license to display the preprint in perpetuity. It is made available under aCC-BY-NC-ND 4.0 International license.

\section{Materials \& Correspondence}

Correspondence and requests for materials should be addressed to J.-L.P. 


\section{Figure legends}

Fig. 1 Tumor phagocytosis triggers the pro-inflammatory activation of macrophages. a, Co-culture model of CMFDA-labeled MDMs and CMTMR-labeled hematologic malignant cells. b, Confocal micrograph of MDMs and Jurkat cells after 8 hours (8h) of co-culture. c,d, Percentage of phagocytosis, determined by the number of MDMs engulfing leukemic cells or PBLs (c) or AML CD34 ${ }^{+}$blasts (d) divided on total MDMs (at least 100 MDMs in five fields) in control (Co.) or ZVAD $(100 \mu \mathrm{M})$ treated co-cultures. e, FACS dot plot of Phago ${ }^{+}$MDMs or Phago ${ }^{-M D M s}$ sorting after $2 \mathrm{~h}$ of co-culture with MOLT4 cells. f-g, Confocal micrographs and percentages of $\mathrm{CMFDA}^{+} \mathrm{CMTMR}^{+} \mathrm{MDMs} 2 \mathrm{~h}\left({ }^{* *} \mathrm{p}=0.0079\right)(\mathbf{f}, \mathbf{g})$ and $96 \mathrm{~h}(\mathbf{h}, \mathbf{i})$ after the sorting of Phago ${ }^{+}$MDMs and Phago ${ }^{-}$MDMs. j-m, Phago ${ }^{+}$MDMs were analyzed, as compared to phago-MDMs, for modulated genes by microarray $\left({ }^{* *} \mathrm{p}=0.0022,{ }^{*} \mathrm{p}=0.0152\right)(\mathbf{j}), \mathrm{CD} 163$ membrane expression by FACS $\left({ }^{* *} \mathrm{p}=0.0039\right)(\mathbf{k})$, IRF5 expression by western blot (WB) (l) and supernatant (SN) indicated pro-inflammatory cytokines by WB (I) or by cytokine microarray $\left({ }^{*} \mathrm{p}=0.0143,{ }^{*} \mathrm{p}=0.05,{ }^{*} \mathrm{p}=0.0286\right.$, respectively $)(\mathbf{m})$ at $96 \mathrm{~h}(\mathbf{j}, \mathbf{k}, \mathbf{m})$ and $7 \mathrm{~d}(\mathbf{l})$ after FACS sorting. n,o, Transwell co-cultures model of Phago ${ }^{+}$MDMs and Phago`MDMs at $2 \mathrm{~h}$ after FACS sorting (n) and iNOS expression by WB of Phago-MDMs co-cultured in the bottom chambers during $15 d(\mathbf{o})$. In $(\mathbf{b}, \mathbf{l}, \mathbf{o})$ and $(\mathbf{e}, \mathbf{f}, \mathbf{h})$ data are representative of $n=3$ and $n=5$ donors. In (c,j), (d) and (g,i) data are means \pm SEM from $n=3, n=6$ and $n=5$ donors. In (d) $\mathrm{CD} 4^{+}$cells are from $n=4$ AML patients. In $(\mathbf{k})$ and $(\mathbf{m})$ data are donor-matched from $n=9$ and in (m) $\mathrm{n}=4$ (for SERPIN E1, IFN $\gamma$ ) and $\mathrm{n}=3$ (for GM-CSF). ${ }^{*} \mathrm{p}<0.05,{ }^{*} \mathrm{p}<0.01$ are determined with two- $(\mathbf{g})$ or one- $(\mathbf{m})$ tailed unpaired Mann-Whitney, Kolmogorov-Smirnov (j) and two-tailed paired Wilcoxon (k), tests.

Fig. 2 Macrophage-expressed p21 governs phagocytosis of leukemic cells through the repression of SIRPa transcription. a, p21 expression by WB in control (siCo.) or p21- 
silenced (sip21) MDMs after 24h siRNAs transfection. b, Confocal micrograph of siCo. or sip21 CMFDA ${ }^{+}$MDMs co-cultured with $\mathrm{CMTMR}^{+}$Jurkat cells for 8 h. c-e, Phagocytosis percentages of Jurkat (c) MOLT4 (d) or patient AML CD34 ${ }^{+}$(e) cells by siCo. or sip21 MDMs after $8 \mathrm{~h}$ co-culture $(* * \mathrm{p}=0.0078, * \mathrm{p}=0.0313, * * * * \mathrm{p}<0.0001)$. f, Phagocytosis rate, determined by fluorescence units (FU), of pHrodo green E. coli bioparticles by siCo. or sip21 MDMs at $2 \mathrm{~h}$. g-i, SIRP $\alpha$ and p21 proteins by WB (g) or mRNAs by qPCR (h,i) in siCo. or sip21 MDMs after $24 \mathrm{~h}$ silencing $\left(* * \mathrm{p}=0.0024,{ }^{*} \mathrm{p}=0.0020\right) . \mathbf{j}-\mathbf{l}, \operatorname{SIRP} \alpha$ and $\mathrm{p} 21$ proteins by WB (j) or mRNAs by qPCR (k,l) in MDMs transduced with control (Co.TD) or p21 (p21TD) expressing lentiviral vectors after $72 \mathrm{~h}$ transductions $(* * p=0.0063, * p=0.0291)$. m, ChIPqPCR assays in control MDMs or in Co.TD $(* * p=0.0016)$ or p21TD $(* * p=0.0017$, $\left.{ }^{*} \mathrm{p}=0.0194\right) \mathrm{MDMs}$ immunoprecipitated with control IgG or anti-p21 antibodies and $\mathrm{qPCR}$ detection of SIRP $\alpha$ promoter, after $72 \mathrm{~h}$ transduction. n,o, Luciferase activities assessed at $24 \mathrm{~h}$ after silencing in siCo or sip21 (n) or at $72 \mathrm{~h}$ after transductions in Co.TD or p21TD (o) MDMs that were transduced with lentiviral vector expressing luciferase reporter gene under $\operatorname{SIRP} \alpha$ promoter $\left({ }^{*} \mathrm{p}=0.0431,{ }^{*} \mathrm{p}=0.0458\right) . \mathbf{p}-\mathbf{r}, \mathrm{MDMs}$ derived from monocytes transduced with control (Co.TD) and/or p21 (p21TD) and/or SIRP $\alpha$ (SIRP $\alpha$ TD) expressing lentiviral vectors assessed for indicated proteins by WB (p) and for phagocytosis of mCherry ${ }^{+}$MOLT4 cells by confocal microscopy $(\mathbf{q})$ and percentages $(\mathbf{r})$ after $8 \mathrm{~h}$ co-culture. In $(\mathbf{a}, \mathbf{b}, \mathbf{g}, \mathbf{j}, \mathbf{p}, \mathbf{q})$ data are representative of $n=3$ donors. In (c), (d), (e), (f,o) and (n) data are donor-matched from $\mathrm{n}=8, \mathrm{n}=6, \mathrm{n}=9, \mathrm{n}=4$ and $\mathrm{n}=3$ donors. In (e) CD $34^{+}$cells are from $\mathrm{n}=6$ AML patients. In (h,i) and $(\mathbf{k}, \mathbf{l}, \mathbf{m}, \mathbf{r})$ data are means \pm SEM from $\mathrm{n}=5$ and $\mathrm{n}=3$ donors. ${ }^{*} \mathrm{p}<0.05,{ }^{*} \mathrm{p}<0.01$, $* * * \mathrm{p}<0.001$ and $* * * * \mathrm{p}<0.0001$ are determined with two-tailed paired Wilcoxon (c,d,e), two$(\mathbf{h}, \mathbf{i}, \mathbf{k}, \mathbf{m})$ or one- (l) tailed ratio-paired t, one-tailed paired t $(\mathbf{n , 0})$ and ANOVA Tukey's multiple comparison (r), tests. 
bioRxiv preprint doi: https://doi.org/10.1101/2022.01.18.476736; this version posted January 20,2022 . The copyright holder for this preprint (which was not certified by peer review) is the author/funder, who has granted bioRxiv a license to display the preprint in perpetuity. It is made available under aCC-BY-NC-ND 4.0 International license.

Fig. 3 Prophylactic adoptive transfer of p21TD-Mo decreases leukemia burden and elongates mice survival in a model of human T-ALL. a, Schematic showing prophylactic adoptive transfer of CFSE-labeled, control (Co.TD), p21 (p21TD) and/or SIRP $\alpha$ (SIRP $\alpha$ TD) genetically engineered human monocytes (Mo) into total body irradiated (TBI) NSG mice which will be engrafted after $7 \mathrm{~d}$ with $\mathrm{mCherry}^{+}$MOLT4 cells. b-k, Engrafted mice, which received indicated monocytes, were assessed at $21 \mathrm{~d}$ for body $(* * \mathrm{p}=0.0079)(\mathbf{b}, \mathbf{c})$ and spleen, $\left({ }^{*} \mathrm{p}=0.00317\right)$ weights $(\mathbf{d}, \mathbf{e})$, for leukemia burden in blood, bone marrow and spleen $\left({ }^{* *} \mathrm{p}=0.0079\right)$ by FACS (all $\left.* * \mathrm{p}=0.0079\right)(\mathbf{f}, \mathbf{g}, \mathbf{h})$ and in liver tissues by confocal microscopy $(* * \mathrm{p}=0.0079)(\mathbf{i}, \mathbf{j})$, and for survival $(* * * \mathrm{p}=0.0003)(\mathbf{k}) . \mathbf{l}$, Survival of engrafted mice, which received indicated monocytes, were treated $21 \mathrm{~d}$ after monocyte transfers with control (Co.) or clodronate (Clodro) containing liposomes $(* * * * p<0.0001)$. $\mathbf{m}$, Survival of engrafted mice that received indicated monocytes $(* * * * \mathrm{p}<0.0001)$. $\mathbf{n , 0}$, Confocal micrographs of phagocytic $\left(\mathrm{CFSE}^{+} \mathrm{mCherry}^{+}\right)$macrophages in spleen (n) and CD163 membrane expression by FACS on sorted single $\mathrm{CFSE}^{+}\left(\mathrm{Phago}^{-}\right) \mathrm{MDMs}$ or phagocytic $\mathrm{CFSE}^{+} \mathrm{mCherry}^{+}\left(\mathrm{Phago}^{+}\right.$) $\mathrm{MDMs}$ from spleen and bone marrow $\left({ }^{*} \mathrm{p}=0.033\right)(\mathbf{0})$ from engrafted mice which received indicated monocytes. p, Survival of engrafted mice that received indicated monocytes and were treated $15 \mathrm{~d}$ after monocyte transfers with isotype control ( $\mathrm{IgG})$ or with anti-IFN $\gamma$ blocking antibodies $(100 \mu \mathrm{g} / \mathrm{mice})(* * * \mathrm{p}=0.0002, * * * * \mathrm{p}<0.0001)$. In $(\mathbf{b}, \mathbf{d}, \mathbf{i}, \mathbf{n})$ data are representative of $\mathrm{n}=5$ mice/group. In (c,e,f,g,h,j) data are means \pm SEM from $n=5$ mice/group. In (k,m), (l) and (p) survival data are from $n=5, n=6$ and $n=7$ mice/group. In (o) data are mouse-matched from $n=3$ mice/group. ${ }^{*} \mathrm{p}<0.05,{ }^{*} \mathrm{p}<0.01, * * * \mathrm{p}<0.001$ and $* * * * \mathrm{p}<0.0001$ are determined with twotailed unpaired Mann-Whiteny (c,e,f,g,h,j), ANOVA Friedman (o) and Mantel-Cox $(\mathbf{k}, \mathbf{l}, \mathbf{m}, \mathbf{p})$, tests. 
bioRxiv preprint doi: https://doi.org/10.1101/2022.01.18.476736; this version posted January $20,2022$. The copyright holder for this preprint (which was not certified by peer review) is the author/funder, who has granted bioRxiv a license to display the preprint in perpetuity. It is made available under aCC-BY-NC-ND 4.0 International license.

Fig. 4 Curative adoptive transfer of p21TD-Mo elongates mice survival in diagnosed or relapsed T-ALL-derived PDX models. a, Schematic showing curative adoptive transfer of Co.TD-Mo or p21TD-Mo in NSG mice that were engrafted with T-ALL PDXs. b-d, Survivals of mice that were engrafted with T-ALL PDX\#1 $(* * * * p<0.0001)(\mathbf{b})$, PDX\#2 $(* * * * p<0.0001)(\mathbf{c})$ and PDX\#3 $(* * p=0.003)(\mathbf{d})$ and received curatively, as shown in (a), Co.TD-Mo or p21TD-Mo. PDX\#1 and PDX\#2 are from the same patient isolated at diagnosis and relapsed stages, respectively. In (b-d) survival data are from $n=5$ mice/group. ${ }^{* *} \mathrm{p}<0.01$ and $* * * * p<0.0001$ are determined with Mantel-Cox (b-d) test. 


\section{a}

Monocyte-derived Hematologic macrophages (MDMs) malignant

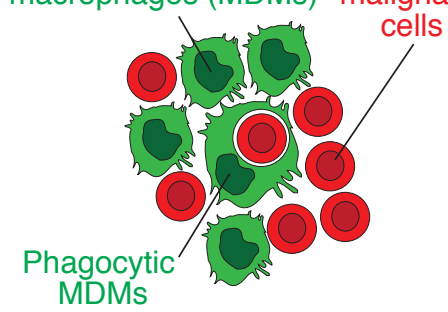

d

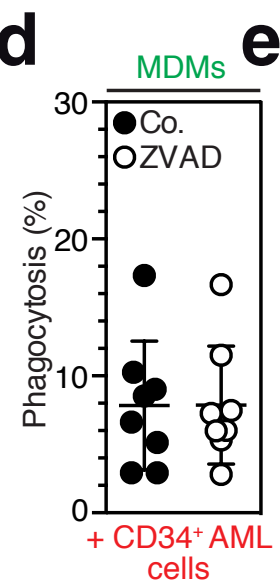

b

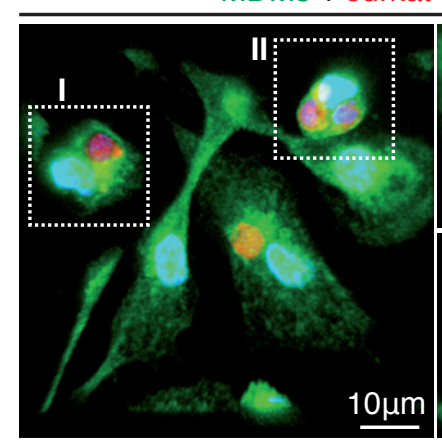

CMFDA CMTMR Nucleus
C

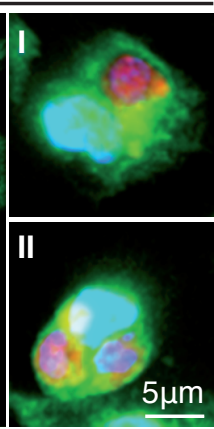

$5 \mu \mathrm{m}$ f $\begin{gathered}\text { Sorted } \\ \text { MDMs (2h) }\end{gathered}$

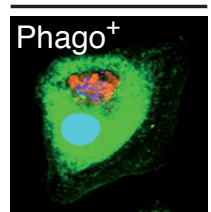

Phago:-

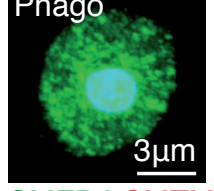

CMFDACMTMR Nucleus
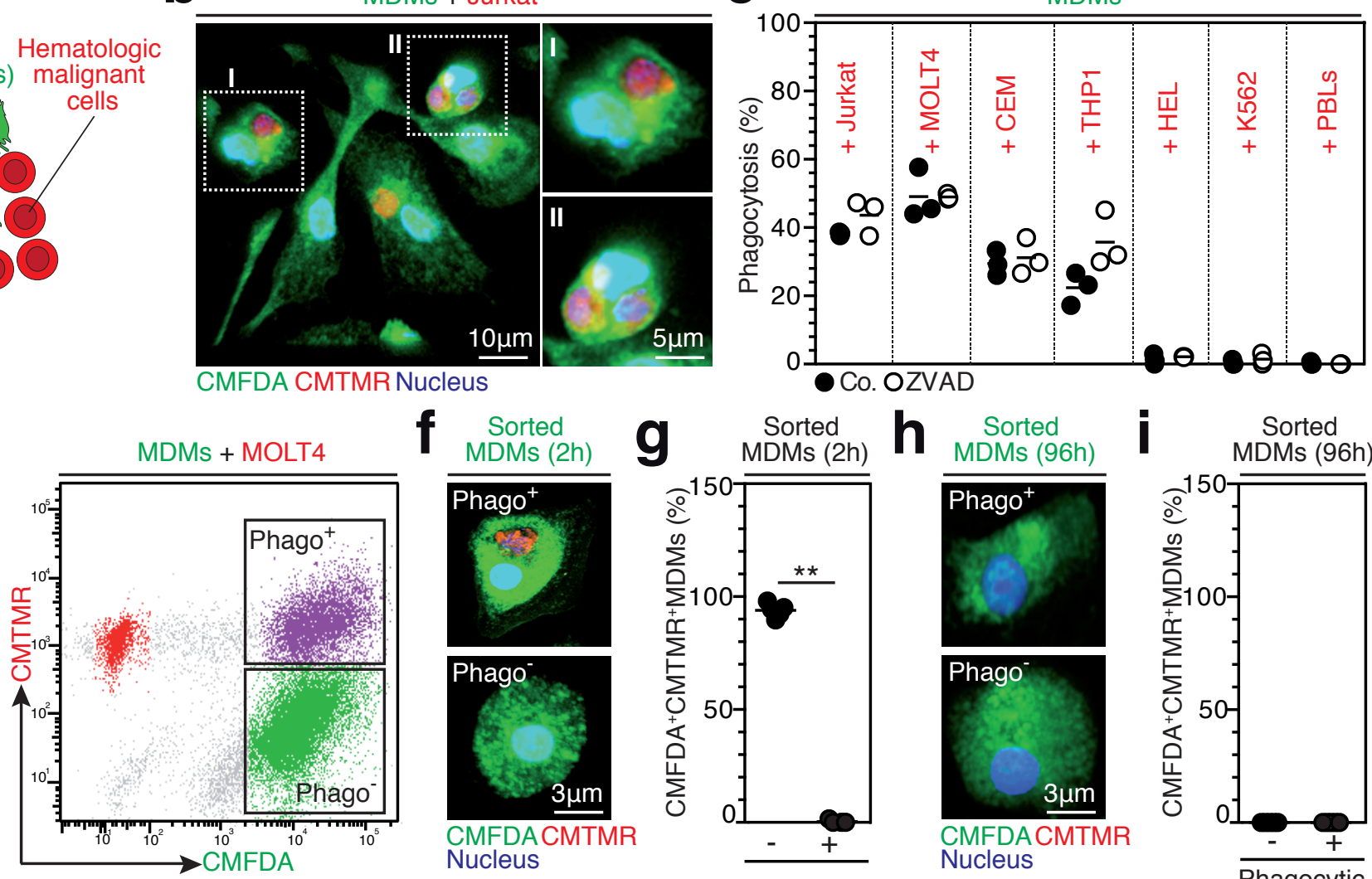

$\mathbf{h} \begin{gathered}\text { Sorted } \\ \text { MDMs (96h) }\end{gathered}$

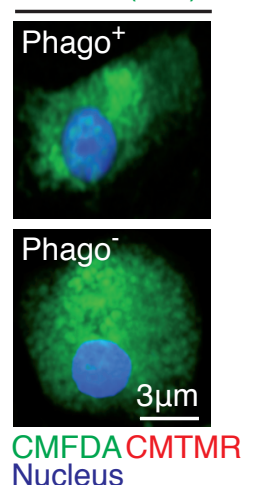
MDMs (96h)

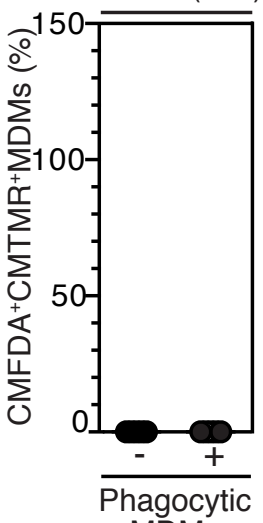

MDMs
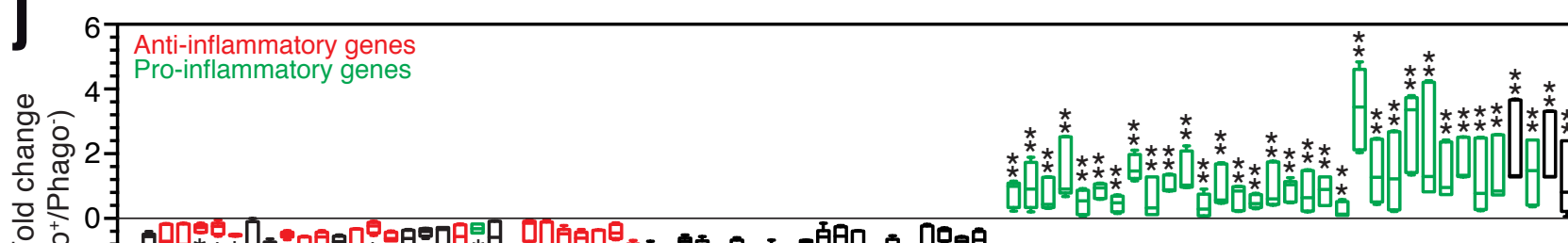

政 오 $=\frac{1}{*}$

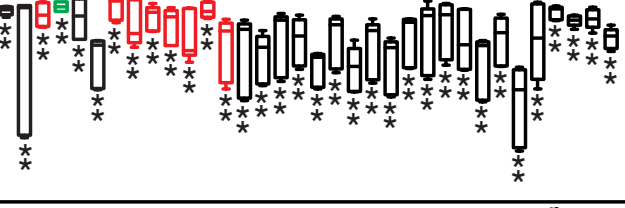

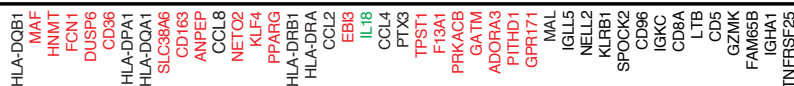

k

$$
\text { ב্ }
$$

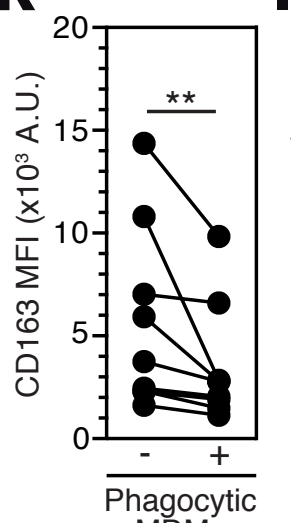

MDMs
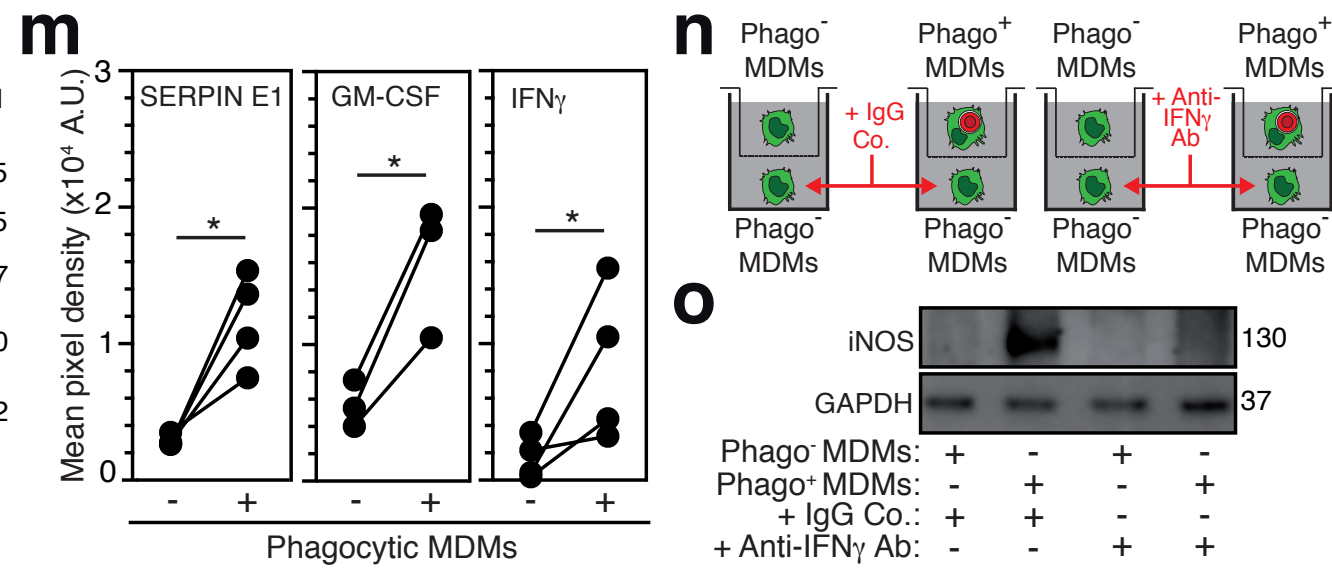

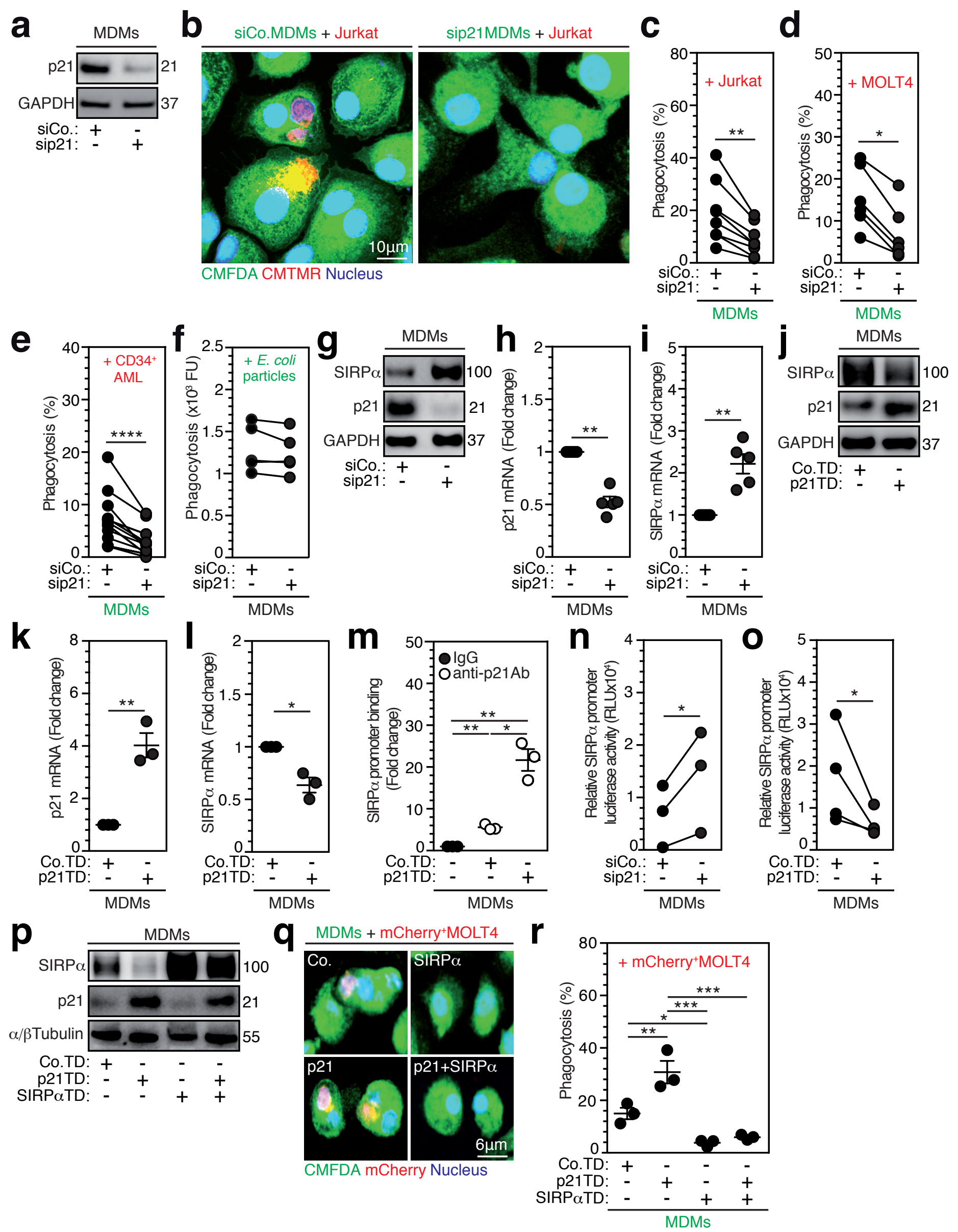
a

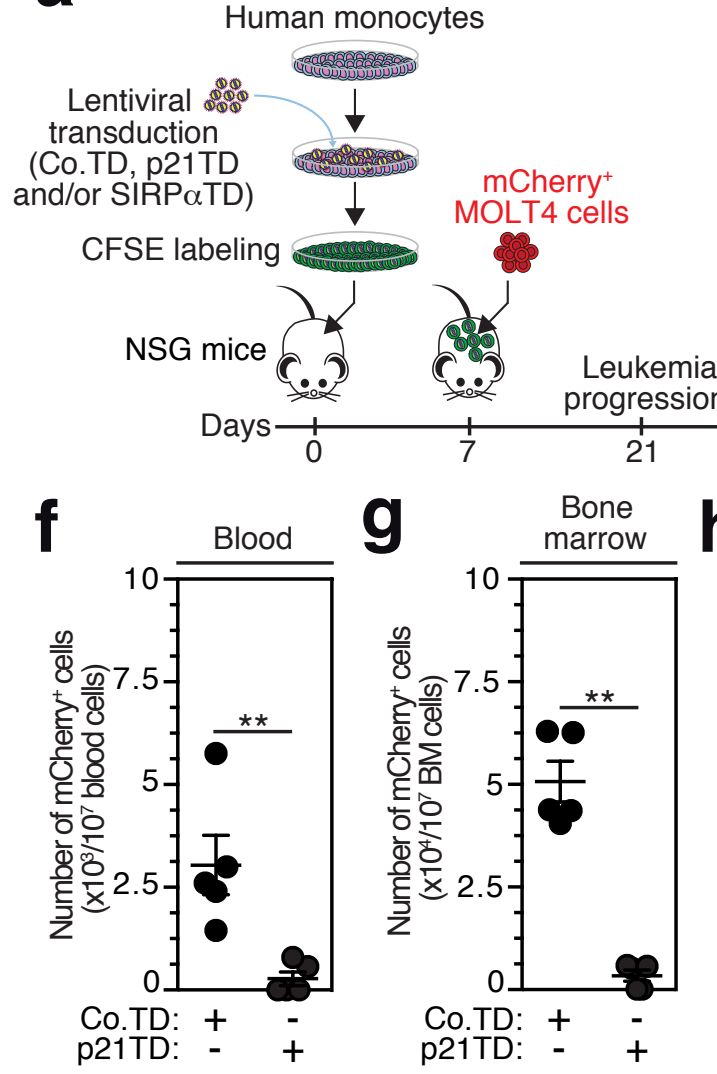

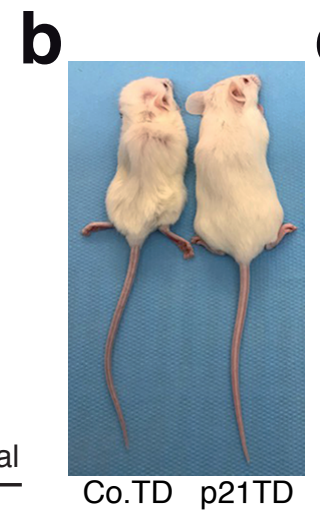

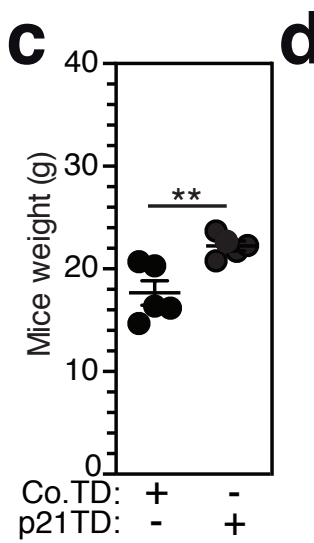

d

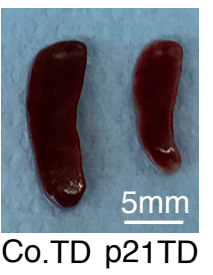

Co.TD p21TD

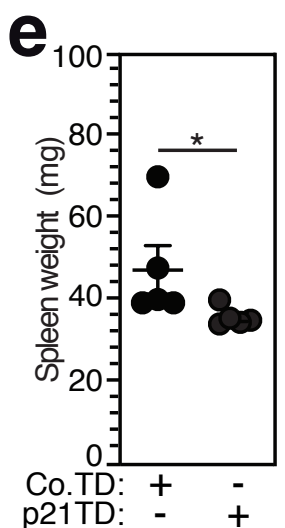

p21TD: $-\quad+$
I

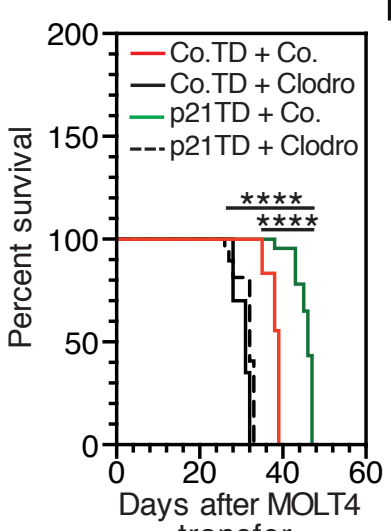

m

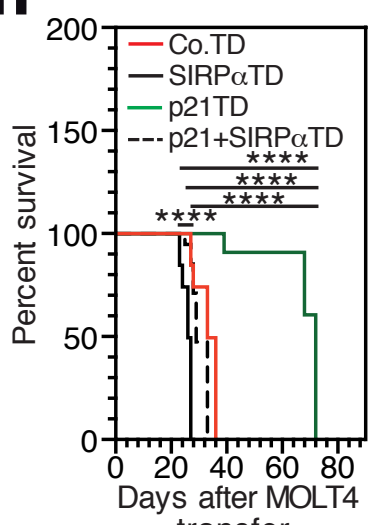

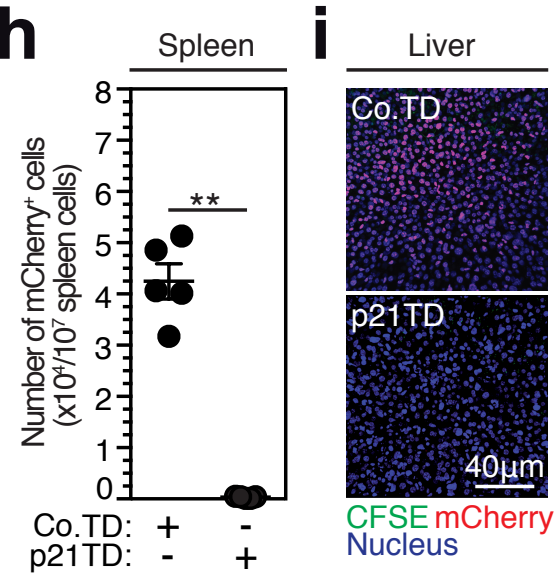

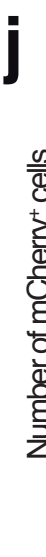
transfer

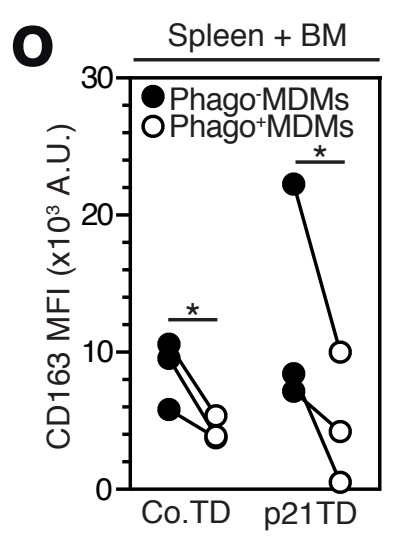

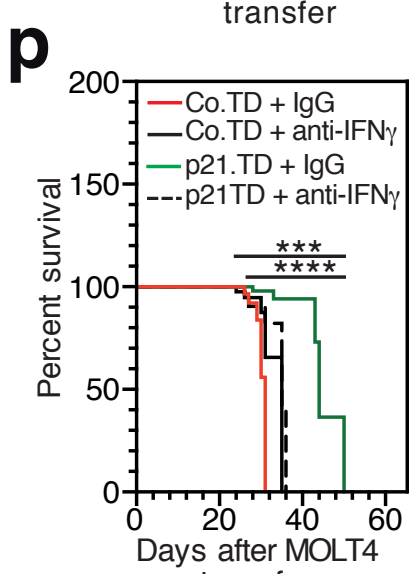


a

T-ALL patients
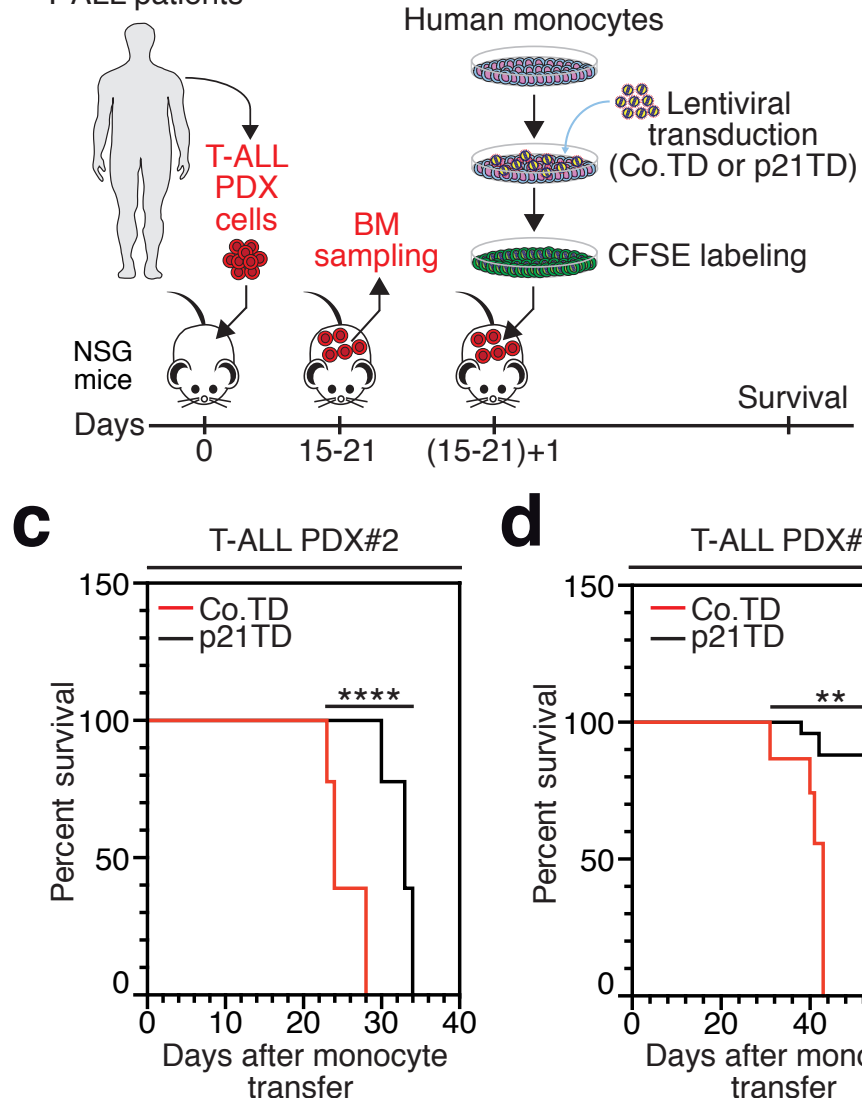

d

T-ALL PDX\#3

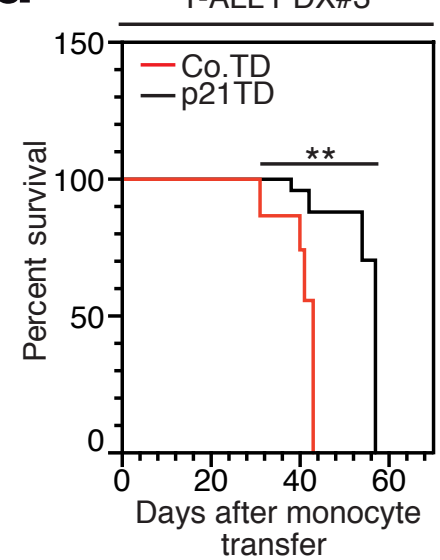

b

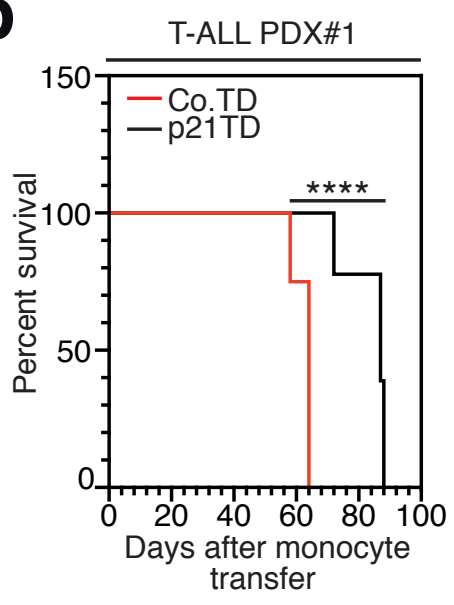

ALLOUCH\#4 